\title{
Conformation Dependence of the SH and CS Stretch Frequencies of the Cysteine Residue
}

\author{
WEILI QIAN and SAMUEL KRIMM \\ Biophysics Research Division and Department of Physics, University of Michigan, Ann Arbor, Michigan 48109
}

\begin{abstract}
SYNOPSIS
In order to relate the observed $\mathrm{SH}$ and $\mathrm{CS}$ stretch frequencies of the cysteine residue in proteins more closely to its conformation, we have done normal mode calculations on a model for this structure, viz., ( $\mathrm{CCONH})(\mathrm{CNHCO}) \mathrm{CHCH}_{2} \mathrm{SH}$. A range of $\chi^{1}$ and $\chi^{2}$ were studied, combined with the $\phi, \psi$ of the $\alpha$-helix, $\beta$-sheet, glutathione, and extended-helix conformations. The force field was a combination of a scaled ab initio force field of the $-\mathrm{CH}_{2} \mathrm{SH}$ group, obtained from ethanethiol and tested on 1-propanethiol and 3-thiol- $\mathrm{N}$ methylpropionamide, and our empirical force field for the peptide group. The results provide more detailed structure--spectra correlations than are possible from experimental studies of model compounds. (C) 1992 John Wiley \& Sons, Inc.
\end{abstract}

\section{INTRODUCTION}

The cysteine residue side chain, $-\mathrm{CH}_{2} \mathrm{SH}$, is an important one in proteins, both because of its inherent properties as well as its ability to react with similar groups to form a disulfide bridge, $\cdot \mathrm{CH}_{2} \mathrm{SSCH}_{2^{-}}$, between polypeptide chains. It is therefore important to develop detailed spectroscopic correlations for characterizing its conformation.

It has long been known that the SH stretch ( $\mathrm{s}$ ) mode, $\nu(\mathrm{SH})$, is generally found in the range of $2500-2600 \mathrm{~cm}^{-1}$, being weak in the ir and strong in the Raman spectrum. Since $\nu(\mathrm{SH})$ is sensitive to the presence of SH groups and to their environment, particularly hydrogen bonding, it has been studied in various proteins, such as hemoglobin, ${ }^{1,2}$ eye lens proteins, ${ }^{3-5} \beta$-lactoglobulin, ${ }^{6}$ and virus proteins. ${ }^{7,8}$ Conformational information with respect to the $\mathrm{C}^{\alpha}$ $\mathrm{C}^{\beta}$-S-H dihedral angle $\left(\chi^{2}\right)$ has been sought through experimental studies of model alkanethiols ${ }^{9-11}$ as well as normal mode calculations on such molecules. ${ }^{12,13}$ Low-frequency torsional modes have also been studied ${ }^{14-16}$ in order to obtain information on rotational barriers.

The $\nu$ (CS) mode has been known to give rise to Raman bands in the $600-800-\mathrm{cm}^{-1}$ region. Confor-

Biopolymers, Vol. 32, 1503-1518 (1992)

CCC $0006-3525 / 92 / 111503-16$ mational assignments with respect to the $\mathrm{C}-\mathrm{C}^{\alpha}{ }_{-} \mathrm{C}^{\beta}$ $\mathrm{S}$ dihedral angle $\left(\chi^{1}\right)$ have been based on experimental studies of thiols, ${ }^{17,18}$ dialkyl disulfides, ${ }^{19,20}$ and alkyl sulfides, ${ }^{21}$ as well as normal mode calculations on these molecules. ${ }^{22,23}$

While these experimental studies on simple model compounds have provided an important base for categorizing conformational states, the results cannot be satisfactorily transferred to a detailed understanding of the structure-spectra correlations in proteins, where, as in the case of the disulfide bridge, ${ }^{24-26}$ the conformations of the adjoining peptide groups are probably important. To achieve such insights requires normal mode analyses with a reliable force field on the relevant structures. In preparing for a vibrational study of glutathione, ${ }^{27}$ we did not feel that current empirical alkanethiol force fields ${ }^{12,13}$ were satisfactory, in part because some of the band assignments in these studies were questionable. Nor did a force field developed for the amino acid cysteine ${ }^{28}$ seem suitable, since it was based in part on the alkanethiol force field ${ }^{13}$ and in any case only considered the residue conformation in the crystal.

We have, therefore, by analogy with the disulfide case, ${ }^{29-31}$ obtained an ab initio force field for the $-\mathrm{CH}_{2} \mathrm{SH}$ group. This was scaled using the experimental data on ethanethiol ${ }^{9,16}(\mathrm{ET})$, and was tested on 1-propanethiol ${ }^{12,17}(1 \mathrm{PT})$, and 3-thiol-N- 
methylpropionamide ${ }^{32}$ (3TNMP), $\mathrm{CH}_{3} \mathrm{NHCOCH}_{2}$ $\mathrm{CH}_{2} \mathrm{SH}$, in the latter case using our ab initio force field for hydrogen-bonded $\mathrm{N}$-methylacetamide ${ }^{33}$ (NMA). The resulting satisfactory agreement justified using the $-\mathrm{CH}_{2} \mathrm{SH}$ force field, together with our empirical force field for the peptide group, ${ }^{34}$ to calculate the $\nu(\mathrm{SH})$ and $\nu(\mathrm{CS})$ modes of a model for the cysteine residue in proteins,

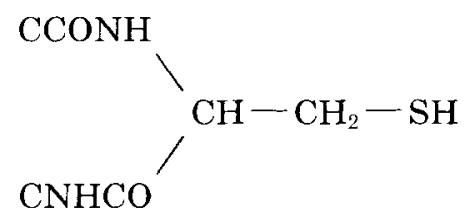

as a function of $\chi^{2}, \chi^{1}$, and the $\phi, \psi$ of the adjacent peptide groups ( $\phi$ and $\psi$ are the $\mathrm{CNC}^{\alpha} \mathrm{C}$ and $\mathrm{NC}^{\alpha} \mathrm{CN}$ dihedral angles, respectively). The results provide greater insight into exactly how these frequencies depend on the complete conformation of the cysteine residue.

\section{AB INITIO FORCE FIELD OF $\mathrm{CH}_{2} \mathrm{SH}$ GROUP}

As noted above, we have based the force field of the $-\mathrm{CH}_{2} \mathrm{SH}$ group on the scaled ab initio force field of $\mathrm{ET}$. The calculational procedures were similar to those used for the disulfide group. ${ }^{30}$ The structure is determined by $\chi^{2}$, which is known to be $\sim 60^{\circ}$ (gauche, $\mathrm{G}$ ) and $\sim 180^{\circ}$ (trans, $\mathrm{T}$ ) for the two stable conformers. ${ }^{9}$ However, since $\chi^{2}$ is more variable in proteins, we have obtained the force field not only at the above minima but also at the energy maxima of $\chi^{2} \sim 0^{\circ}$ (cis, C) and $\sim 120^{\circ}$ (skew, S). This provides, as in the case of the disulfide group, ${ }^{31}$ a conformation-dependent force field.

The restricted Hartree-Fock calculations were done using Gaussian 86 with a $3-21 G^{*}$ basis set, the same basis set as was used for the disulfide calculations. ${ }^{30}$ (A calculation was also done with a $4-31 \mathrm{G}^{*}$ basis set, but the results were not significantly different.) Force constants were calculated in cartesian coordinates by the analytical method at the optimized C, G, S, and T geometries. They were then transformed into internal coordinates using a numerical method for determining the redundant coordinates. ${ }^{30}$ Force constants for negative $\chi^{2}, \mathrm{G}^{\prime}$ and $\mathrm{S}^{\prime}$, can easily be obtained from their positive counterparts. ${ }^{24}$ Since force constants obtained with such limited basis sets are generally too high, we have scaled them according to a standard procedure. ${ }^{35}$ Because of the similarity of parts of the ET molecule to the disulfide group, we initially transferred related scale factors from the latter ${ }^{30}$ and subsequently refined all scale factors to improve agreement with the experimental data.

The structures of the four conformers are shown in Figure 1 and their optimized geometric parameters are given in Table I. A dihedral angle of $\chi^{2}$ $=64.8^{\circ}$ has been obtained for the $\mathrm{G}$ conformer from analysis of higher level torsional transitions, ${ }^{16}$ which compares very well with our calculated value of $64.5^{\circ}$. The relative energies, in $\mathrm{kcal} / \mathrm{mole}$, are $\mathrm{G}=0$, $\mathrm{T}=0.317, \mathrm{~S}=1.619$, and $\mathrm{C}=1.906$. (The $4-31 \mathrm{G}^{*}$ relative energies are $\mathrm{G}=0, \mathrm{~T}=0.546, \mathrm{~S}=1.666$, and $\mathrm{C}=2.054$.) This leads to $\Delta E(\mathrm{G}-\mathrm{T})=0.317$ (compared to an experimental value of $0.336^{16}$ ) and barriers of $\mathrm{G} \rightarrow \mathrm{T}=1.619\left(1.410^{16}\right), \mathrm{T} \rightarrow \mathrm{G}=1.302$ $\left(1.028^{16}\right)$, and $G \rightarrow G^{\prime}=1.906\left(1.764^{16}\right)$, which are all in acceptable agreement with experiment.

The internal and local symmetry coordinates are defined in Tables II and III, respectively. The band assignments for the G conformer of gaseous ET are quite secure ${ }^{9,13-16}$ and therefore the refinement of scale factors was straightforward; these are given in Table IV. The scaled ab initio force field (for force constants $\geq 0.03$ ) is given in Table $V$. The calculated frequencies based on the full $a b$ initio force field, with their potential energy distributions (PED), are given in Table VI for the $\mathrm{G}$ and $\mathrm{T}$ conformers. They are compared with observed gas-phase

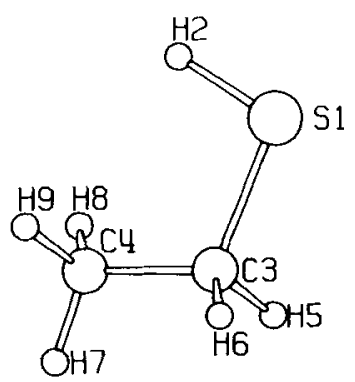

C

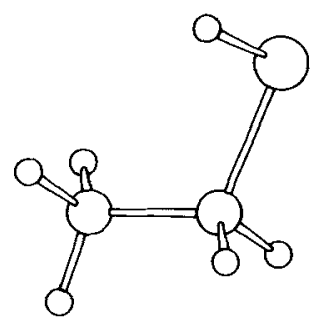

G

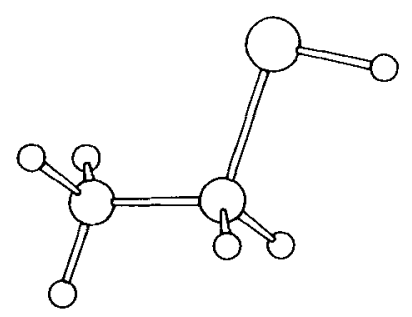

T

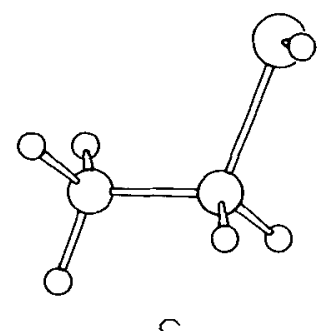

$S$
Figure 1. Conformations and atom numberings of $\mathrm{C}$, $\mathrm{T}, \mathrm{G}$, and $\mathrm{S}$ conformers of ET. 
Table I Optimized Geometric Parameters of Ethanethiol Conformers

\begin{tabular}{|c|c|c|c|c|}
\hline \multirow[b]{2}{*}{ Parameter ${ }^{\mathrm{a}}$} & \multicolumn{4}{|c|}{ Conformer } \\
\hline & $\mathrm{G}$ & $\mathrm{T}$ & $\mathbf{S}$ & $\mathrm{C}$ \\
\hline $\mathrm{CC}$ & 1.538 & 1.541 & 1.539 & 1.539 \\
\hline CS & 1.826 & 1.829 & 1.838 & 1.838 \\
\hline $\mathrm{SH}$ & 1.328 & 1.327 & 1.325 & 1.326 \\
\hline $\mathrm{CH} 5$ & 1.082 & 1.081 & 1.080 & 1.080 \\
\hline $\mathrm{CH} 6$ & 1.081 & 1.081 & 1.081 & 1.080 \\
\hline $\mathrm{CH} 7$ & 1.085 & 1.084 & 1.085 & 1.084 \\
\hline $\mathrm{CH} 8$ & 1.082 & 1.083 & 1.083 & 1.083 \\
\hline $\mathrm{CH9}$ & 1.084 & 1.083 & 1.082 & 1.083 \\
\hline $\mathrm{CSH}$ & 97.4 & 97.9 & 98.1 & 98.0 \\
\hline $\operatorname{CCS}$ & 113.5 & 109.2 & 111.9 & 113.4 \\
\hline $\mathrm{SCH} 5$ & 105.1 & 109.4 & 107.9 & 107.5 \\
\hline SCH6 & 109.3 & 109.4 & 108.4 & 107.6 \\
\hline $\mathrm{CCH7}$ & 110.1 & 109.8 & 110.0 & 109.8 \\
\hline $\mathrm{CCH} 8$ & 110.5 & 110.7 & 110.7 & 110.8 \\
\hline CCH9 & 110.8 & 110.7 & 110.5 & 110.8 \\
\hline $\mathrm{CCSH}$ & 64.5 & 181.5 & 119.8 & 0.7 \\
\hline $\mathrm{H} 5 \mathrm{CSH}$ & -175.1 & -58.1 & -118.6 & 122.4 \\
\hline $\mathrm{H} 6 \mathrm{CSH}$ & -59.8 & 61.1 & -2.0 & -121.1 \\
\hline $\mathrm{H} 7 \mathrm{CCS}$ & 176.7 & 180.5 & 179.4 & 179.9 \\
\hline $\mathrm{H} 8 \mathrm{CCS}$ & 56.4 & 60.7 & 59.7 & 60.3 \\
\hline H9CCS & -63.7 & -59.8 & -60.3 & -60.5 \\
\hline
\end{tabular}

${ }^{a}$ Bond lengths in $\AA$, bond angles in degrees. Numbered H atoms refer to Figure 1.

frequencies $^{9,14-16}$ and with condensed phase data. ${ }^{9}$ Calculated ir and Raman intensities are also given.

The agreement between observed gas-phase frequencies and those calculated for the $\mathrm{G}$ conformer is excellent. The one exception is the $\mathrm{CH}_{2}$ rock ( $\mathrm{r}$ ) mode, calculated at $718 \mathrm{~cm}^{-1}$ and observed at 736 $\mathrm{cm}^{-1}$ ( unless the very weak $725-\mathrm{cm}^{-1}$ band ${ }^{16}$ is assignable to this mode). Its observed shift to $781 \mathrm{~cm}^{-1}$ in the $\mathrm{T}$ conformer, ${ }^{9}$ however, is reasonably well reproduced by the calculation. [ We should note that the observed difference between $\nu_{\mathrm{G}}(\mathrm{SH})$ and $\nu_{\mathrm{T}}(\mathrm{SH})$ can be accounted for by the difference in force constants $f(\mathrm{SH})$ that results from differences in electronic structure between the conformers (cf. Table $\mathrm{V})$, since an unchanged $f(\mathrm{SH})$ results in an unchanged $\nu(\mathrm{SH})$. It is therefore unnecessary to invoke an interaction between $\mathrm{SH}$ s and CCSH torsion, ${ }^{10}$ (t) which in any case is very small (cf. Table V), in order to account for this difference. That $\Delta \nu$ (calc) $=3 \mathrm{~cm}^{-1}$ compared to $\Delta \nu$ (obs) $=9 \mathrm{~cm}^{-1}$ may be due to the limited basis set used in our ab initio calculation or to anharmonicity effects.] For the few bands assignable to the $T$ conformer, the agreement is good and the assignments are reasonable. How- ever, it has been proposed ${ }^{16}$ that some of these bands may be combinations or hot bands (e.g., $855=\mathrm{CS}$ $\mathrm{s}+0 \rightarrow 1 \mathrm{CS} \mathrm{t}, 232=1 \rightarrow 2 \mathrm{CC} \mathrm{t}, 157=1 \rightarrow 2 \mathrm{CS}$ t). There was no such assignment for the $675-\mathrm{cm}^{-1}$ band, ${ }^{16}$ and it and the $781-\mathrm{cm}^{-1}$ band are convincingly assigned to the $\mathrm{T}$ conformer, ${ }^{9}$ so it may be necessary to reexamine such alternate assignments. ${ }^{16}$ After all, if $\Delta E(\mathrm{G}-\mathrm{T})$ is $0.336 \mathrm{kcal} / \mathrm{mole},{ }^{16}$ there should be $\sim 36 \%$ of the $\mathrm{T}$ conformer in the sample.

The ab initio force field also accounts convincingly for the frequency shifts on deuteration (Table VII). The $\nu(\mathrm{SH})$ mode of the $\mathrm{G}$ conformer shifts from 2594 (calculated at 2594) to $1881(1866) \mathrm{cm}^{-1}$; this discrepancy is undoubtedly due to the different (and large) anharmonicities of the SH and SD modes (the ab initio calculation of course gives harmonic frequencies). The shift of the $\mathrm{CH}_{3} \mathrm{r} 1 / \mathrm{CSH}$ bend (b) mode from 1098 (1100) to 1069 (1064) $\mathrm{cm}^{-1}$ is well reproduced. The CSH b mode at 870 (870) $\mathrm{cm}^{-1}$ moves to $625(610) \mathrm{cm}^{-1}$, a reasonable prediction in view of the different anharmonicities. What is particularly gratifying is that shifts of modes not involving significant $\mathrm{SH}$ contributions are well predicted, viz., CS s for G [662 (662) to $676(670)$ $\mathrm{cm}^{-1}$ ] and $\mathrm{T}\left[675(672)\right.$ to $\left.696(704) \mathrm{cm}^{-1}\right]$ conformers, and CS t for G [191 (191) to 150 (144)

Table II Internal Coordinates of ET ${ }^{\mathrm{a}}$
$\mathrm{R} 1=\Delta r(\mathrm{~S} 1-\mathrm{H} 2)$

$\mathrm{R} 2=\Delta r(\mathrm{~S} 1-\mathrm{C} 3)$

$\mathrm{R} 3=\Delta r(\mathrm{C} 3-\mathrm{C} 4)$

$\mathrm{R} 4=\Delta r(\mathrm{C} 3--\mathrm{H} 5)$

$\mathrm{R} 5=\Delta r(\mathrm{C} 3--\mathrm{H} 6)$

$\mathrm{R} 6=\Delta r(\mathrm{C} 4-\mathrm{H} 7)$

$\mathrm{R} 7=\Delta r(\mathrm{C} 4-\mathrm{H} 8)$

$\mathrm{R} 8=\Delta r(\mathrm{C} 4-\mathrm{H} 9)$

$\mathrm{R} 9=\Delta \theta(\mathrm{C} 3-\mathrm{S} 1-\mathrm{H} 2)$

$\mathrm{R} 10=\Delta \theta(\mathrm{C} 4-\mathrm{C} 3-\mathrm{S} 1)$

$\mathrm{R} 11=\Delta \theta(\mathrm{S} 1-\mathrm{C} 3-\mathrm{H} 5)$

$\mathrm{R} 12=\Delta \theta(\mathrm{S} 1-\mathrm{C} 3-\mathrm{H} 6)$

$\mathrm{R} 13=\Delta \theta(\mathrm{C} 4-\mathrm{C} 3-\mathrm{H} 5)$

$\mathrm{R} 14=\Delta \theta(\mathrm{H} 5-\mathrm{C} 3-\mathrm{H} 6)$

$\mathrm{R} 15=\Delta \theta(\mathrm{C} 4-\mathrm{C} 3-\mathrm{H} 6)$

$\mathrm{R} 16=\Delta \theta(\mathrm{C} 3-\mathrm{C} 4-\mathrm{H} 9)$

$\mathrm{R} 17=\Delta \theta(\mathrm{C} 3-\mathrm{C} 4-\mathrm{H} 7)$

$\mathrm{R} 18=\Delta \theta(\mathrm{C} 3-\mathrm{C} 4-\mathrm{H} 8)$

$\mathrm{R} 19=\Delta \theta(\mathrm{H} 7-\mathrm{C} 4-\mathrm{H} 9)$

$\mathrm{R} 20=\Delta \theta(\mathrm{H} 7-\mathrm{C} 4-\mathrm{H} 8)$

$\mathrm{R} 21=\Delta \theta(\mathrm{H} 8-\mathrm{C} 4-\mathrm{H} 9)$

$\mathrm{R} 22=\Delta \tau(\mathrm{C} 3 \mathrm{~S} 1)$

$\mathrm{R} 23=\Delta \tau(\mathrm{C} 3 \mathrm{C} 4)$

${ }^{\mathrm{B}}$ For atom numbering, see Figure 1. 
Table III Local Symmetry Coordinates of ET

\begin{tabular}{|c|c|}
\hline Symmetry Coordinates & Description \\
\hline $\mathrm{S} 1=\mathrm{R} 1$ & $\mathrm{SH}$ s \\
\hline $\mathbf{S} 2=\mathbf{R} 2$ & $\mathrm{CS} \mathrm{s}$ \\
\hline $\mathrm{S} 3=\mathrm{R} 3$ & $\mathrm{CC} \mathrm{s}$ \\
\hline $\mathrm{S} 4=\mathrm{R} 4+\mathrm{R} 5$ & $\mathrm{CH}_{2}$ ss \\
\hline $\mathrm{S} 5=\mathrm{R} 4-\mathrm{R} 5$ & $\mathrm{CH}_{2}$ as \\
\hline $\mathrm{S} 6=\mathrm{R} 6+\mathrm{R} 7+\mathrm{R} 8$ & $\mathrm{CH}_{3} \mathrm{ss}$ \\
\hline $\mathrm{S} 7=\mathrm{R} 6-\mathrm{R} 7$ & $\mathrm{CH}_{3}$ as1 \\
\hline $\mathrm{S} 8=2 \mathrm{R} 8-\mathrm{R} 6-\mathrm{R} 7$ & $\mathrm{CH}_{3}$ as2 \\
\hline $\mathrm{S} 9=\mathrm{R} 9$ & $\mathrm{CSH} \mathrm{b}$ \\
\hline $\mathrm{S} 10=5 \mathrm{R} 10-\mathrm{R} 11-\mathrm{R} 12-\mathrm{R} 13-\mathrm{R} 14-\mathrm{R} 15$ & $\operatorname{CCS} d$ \\
\hline $\mathrm{S} 11=4 \mathrm{R} 14-\mathrm{R} 11-\mathrm{R} 12-\mathrm{R} 13-\mathrm{R} 15$ & $\mathrm{CH}_{2} \mathbf{b}$ \\
\hline $\mathrm{S} 12=\mathrm{R} 13+\mathrm{R} 15-\mathrm{R} 11-\mathrm{R} 12$ & $\mathrm{CH}_{2} \mathrm{w}$ \\
\hline $\mathrm{S} 13=\mathrm{R} 13+\mathrm{R} 11-\mathrm{R} 12-\mathrm{R} 15$ & $\mathrm{CH}_{2}$ tw \\
\hline $\mathrm{S} 14=\mathrm{R} 11+\mathrm{R} 15-\mathrm{R} 12-\mathrm{R} 13$ & $\mathrm{CH}_{2} \mathrm{r}$ \\
\hline $\mathrm{S} 15=\mathrm{R} 19+\mathrm{R} 20+\mathrm{R} 21-\mathrm{R} 16-\mathrm{R} 17-\mathrm{R} 18$ & $\mathrm{CH}_{3} \mathrm{sb}$ \\
\hline $\mathrm{S} 16=2 \mathrm{R} 20-\mathrm{R} 19-\mathrm{R} 21$ & $\mathrm{CH}_{3}$ ab1 \\
\hline $\mathrm{S} 17=\mathbf{R} 19-\mathbf{R} 21$ & $\mathrm{CH}_{3} \mathrm{ab} 2$ \\
\hline $\mathrm{S} 18=2 \mathrm{R} 16-\mathrm{R} 17-\mathrm{R} 18$ & $\mathrm{CH}_{3} \mathbf{r} 1$ \\
\hline $\mathrm{S} 19=\mathrm{R} 17-\mathrm{R} 18$ & $\mathrm{CH}_{3} \mathbf{r} 2$ \\
\hline $\mathrm{S} 20=\mathbf{R} 22$ & $\mathrm{CS} t$ \\
\hline $\mathrm{S} 21=\mathbf{R} 23$ & $\mathrm{CC} \mathrm{t}$ \\
\hline $\mathrm{S} 22=\mathrm{R} 10+\mathrm{R} 11+\mathrm{R} 12+\mathrm{R} 13+\mathrm{R} 14+\mathrm{R} 15$ & Red 1 \\
\hline $\mathrm{S} 23=\mathrm{R} 16+\mathrm{R} 17+\mathrm{R} 18+\mathrm{R} 19+\mathrm{R} 20+\mathrm{R} 21$ & Red 2 \\
\hline
\end{tabular}

${ }^{a}$ s: stretch; ss: symmetric stretch; as: antisymmetric stretch; b: bend, sb: symmetric bend; ab: antisymmetric bend; d: deformation; w: wag; r: rock; tw: twist; t: torsion; Red: redundancy.

$\left.\mathrm{cm}^{-1}\right]$ and $\mathrm{T}\left[157\right.$ (166) to $\left.136(125) \mathrm{cm}^{-1}\right]$ conformers. Thus, this force field should be transferable to other molecules with $\mathrm{SH}$ groups.

\section{FORCE FIELD OF CYSTEINE RESIDUE}

In order to properly predict the modes of the cysteine residue in proteins, we need to be sure that the force field can satisfactorily reproduce the dependence of $\nu(\mathrm{SH})$ and $\nu(\mathrm{CS})$ on $\chi^{1}$, and, as found in the disulfide case, ${ }^{26}$ the differences introduced by adjacent peptide groups. We have examined the first point by transferring our ab initio force field to calculations of the modes of $1 \mathrm{P}^{\prime} \mathrm{T}$, the simplest relevant molecule that can exhibit a $\chi^{1}$ dependence, and 3TNMP, a molecule containing an adjacent peptide group and for which the effects of hydrogen bonding can also be examined.

\section{1-Propanethiol}

The force field used in the calculation of the normal modes of $1 \mathrm{PT}$ consisted of two parts: the ab initio force field for the $-\mathrm{C}^{\beta} \mathrm{H}_{2} \mathrm{SH}$ portion of the molecule, taken from that of ET, and an empirical force field for the $\mathrm{CH}_{3} \mathrm{C}^{\alpha} \mathrm{H}_{2}$ - hydrocarbon part of the molecule. ${ }^{36}$ This combined force field gave reasonably good frequency agreement with the frequencies of the expected predominant $\chi^{1} \chi^{2}=$ TG conformer, ${ }^{13}$ particularly in the low-temperature liquid ${ }^{12}$ (we agree with this TG assignment ${ }^{13}$ but not with the proposed TT or GT assignments ${ }^{12}$ ). We then did a least-squares refinement of the empirical force constants (which is not unreasonable in merging two such force fields) to optimize the agreement. The force constant changes were very small, and we then applied this force field to the calculation of the normal modes of the five possible conformers. The results are given in Table VIII.

In making the assignments proposed in the table, we were guided by the consideration that, while the energy of the TG conformer is the lowest, those of GG and TT may well be about equal to each other because of the roughly comparable $\Delta E(T-G)$ for $\chi^{1}$ and $\chi^{2}$. We find that some spectral results, particularly in comparing band intensities between gas ( $g$ ) room-temperature liquid $\left(l_{R}\right)$, and low-temper- 
Table IV Scale Factors for ET and 3TNMP Force Constants

\begin{tabular}{|c|c|c|c|}
\hline Internal Coordinate $^{a}$ & ET & 3TNMP & Ratio $^{b}$ \\
\hline $\mathrm{SH} \mathrm{s}$ & 0.8084 & 0.7826 & 0.9681 \\
\hline $\mathrm{CS} \mathrm{s}$ & 0.9045 & 0.9061 & 1.0018 \\
\hline $\mathrm{CC} \mathrm{s}$ & 0.9771 & 0.9281 & 0.9499 \\
\hline $\mathrm{C}^{\beta} \mathrm{H} \mathrm{s}$ & 0.8255 & & \\
\hline $\mathrm{C}^{\alpha} \mathrm{H} \mathrm{s}$ & 0.8189 & & \\
\hline $\mathrm{CSH} b$ & 0.7841 & 0.7626 & 0.9726 \\
\hline CCS b & 0.8451 & 0.9470 & 1.1206 \\
\hline $\mathrm{SCH} b$ & 0.7602 & 0.8431 & 1.1090 \\
\hline $\mathrm{C}^{\alpha} \mathrm{C}^{\beta} \mathrm{H} \mathrm{b}$ & 0.7904 & 0.6718 & 0.8499 \\
\hline $\mathrm{C}^{\beta} \mathrm{C}^{\alpha} \mathrm{H} \mathrm{b}$ & 0.7685 & 0.8679 & 1.1294 \\
\hline $\mathrm{HC}^{\beta} \mathrm{H} \mathrm{b}$ & 0.7558 & 0.7410 & 0.9804 \\
\hline $\mathrm{HC}^{\alpha} \mathrm{H} \mathrm{b}$ & 0.7528 & 0.7405 & 0.9837 \\
\hline $\mathrm{CC} \mathrm{t}$ & 0.8590 & 0.8590 & 1.0000 \\
\hline $\mathrm{CS} \mathrm{t}$ & 0.6246 & 0.6246 & 1.0000 \\
\hline $\mathrm{CN} \mathrm{s}$ & & 0.8318 & 0.9442 \\
\hline $\mathrm{COs}$ & & 0.6962 & 1.0423 \\
\hline $\mathrm{CC}^{\alpha}$ and $\mathrm{NC}\left(\mathrm{H}_{3}\right) \mathrm{s}$ & & 0.8284 & 0.9827 \\
\hline $\mathrm{CNC}, \mathrm{NCC}^{\alpha}, \mathrm{NCO}$, and $\mathrm{C}^{\alpha} \mathrm{CO} \mathrm{d}$ & & 0.7881 & 0.8651 \\
\hline $\mathrm{CNH} \mathrm{b}$ & & 0.8118 & 1.0667 \\
\hline $\mathrm{NCH} \mathrm{b}$ & & 0.7474 & 0.9558 \\
\hline $\mathrm{HC}\left(\mathrm{H}_{3}\right) \mathrm{H} \mathrm{b}$ & & 0.7686 & 0.9879 \\
\hline $\mathrm{NH} \mathrm{ob}$ & & 0.8849 & 1.0056 \\
\hline $\mathrm{CO}$ ob & & 1.0179 & 1.1567 \\
\hline $\mathrm{CN} \mathrm{t}$ & & 0.8752 & 0.9946 \\
\hline $\mathrm{CC}$ and $\mathrm{NC} t^{\mathrm{c}}$ & & 1.0000 & 1.0000 \\
\hline
\end{tabular}

${ }^{a}$ s: stretch; b: bend, ob: out-of-plane bend; d: deformation; t: torsion.

${ }^{\mathrm{b}}$ Ratio of 3 TNMP to ET or N-methylacetamide ${ }^{33}$ scale factors.

${ }^{\mathrm{c}}$ From empirical force field. ${ }^{34}$

ature liquid $\left(l_{L}\right)$, indicate the presence of $T T$ as well as GG conformers (contrary to previous assumptions ${ }^{13}$ ), while there is no evidence for the necessary presence of $\mathrm{G}^{\prime} \mathrm{G}$ or GT.

The predominance of the TG conformer in the $l_{L}$ phase is attested to by the excellent agreement between the observed band frequencies and intensities and the frequencies calculated for the various conformers. This is particularly true in view of the presence of unique TG bands at 961, 898, and (probably) $781 \mathrm{~cm}^{-1}$, and the weakened band at $\sim 790 \mathrm{~cm}^{-1}$ and absent band at $655 \mathrm{~cm}^{-1}$. The presence of the GG conformer in the $g$ and $l_{R}$ phases is supported by bands at 1210, 920, 880, 793, and $655 \mathrm{~cm}^{-1}$ (although some of these coincide with bands of the $G^{\prime} G$ conformer). The intensity change at $\sim 1085 \mathrm{~cm}^{-1}$ indicates the likely presence of the TT conformer in these phases. The strong bands at 706 and $736 \mathrm{~cm}^{-1}$ undoubtedly result from a Fermi resonance between $\mathrm{CS} \mathrm{s}$ and the overtone of $\mathrm{CCC}$ deformation (d) (as previously suggested ${ }^{17}$ ), and several other combination bands are readily indicated. Incidentally, the slightly lower observed $v(\mathrm{SH})$ (compared to $\mathrm{ET}$ ), with a necessarily smaller $f(\mathrm{SH})$ to give closer agreement, probably reflects the presence of hydrogen bonding, at least in the liquid.

Thus, reasonable assignments can be made for $1 \mathrm{PT}$, the results of which show that the ab initio force field provides a reliable description of the conformation dependence of frequencies associated with the $-\mathrm{CH}_{2} \mathrm{SH}$ group.

\section{3-Thiol-N-Methylpropionamide}

No crystal structure has been reported for 3TNMP, and we have therefore used aqueous solution data ${ }^{32}$ in refining the scale factors for this molecule (these frequencies are in fact close to those of the solid ${ }^{32}$ ). In order to provide a relevant model for the normal mode calculations, we have placed $\mathrm{H}$ and $\mathrm{O}$ atoms in hydrogen-bonding positions appropriate to the peptide group, taken from NMA, ${ }^{33}$ and to the $\mathrm{SH}$ 
Table V Scaled Ab Initio Force Field of ET for Different Conformers (Force Constants $\geq 0.03$ )

\begin{tabular}{|c|c|c|c|c|c|c|c|c|c|}
\hline \multirow{2}{*}{$\begin{array}{c}\text { Force } \\
\text { Constant }^{\mathrm{a}}\end{array}$} & \multicolumn{4}{|c|}{ Value $^{b}$} & \multirow{2}{*}{$\begin{array}{c}\text { Force } \\
\text { Constant }^{a}\end{array}$} & \multicolumn{4}{|c|}{ Value $^{b}$} \\
\hline & $\mathrm{C}$ & $\mathrm{G}$ & $\mathbf{S}$ & $\mathrm{T}$ & & $\mathrm{C}$ & $\mathrm{G}$ & $\mathrm{S}$ & $\mathrm{T}$ \\
\hline SH & 3.903 & 3.875 & 3.914 & 3.882 & $\mathrm{CH} 7 / \mathrm{CCH} 9$ & -0.067 & -0.067 & -0.068 & -0.067 \\
\hline $\mathrm{SH} / \mathrm{CCS}$ & -0.043 & -0.011 & 0.010 & 0.026 & $\mathrm{CH} 7 / \mathrm{CCH} 7$ & 0.052 & 0.054 & 0.055 & 0.054 \\
\hline $\mathrm{SC}$ & 3.012 & 3.064 & 3.016 & 3.044 & CH7/CCH8 & -0.067 & -0.068 & -0.068 & -0.067 \\
\hline $\mathrm{SC} / \mathrm{CC}$ & 0.145 & 0.181 & 0.194 & 0.181 & $\mathrm{CH} 7 / \mathrm{HCHa}$ & 0.079 & 0.080 & 0.077 & 0.079 \\
\hline $\mathrm{SC} / \mathrm{CH} 5$ & 0.076 & 0.079 & 0.074 & 0.070 & $\mathrm{CH} 7 / \mathrm{HCHb}$ & 0.079 & 0.077 & 0.079 & 0.079 \\
\hline $\mathrm{SC} / \mathrm{CH} 6$ & 0.076 & 0.068 & 0.030 & 0.072 & $\mathrm{CH} 7 / \mathrm{HCHc}$ & -0.072 & -0.072 & -0.072 & -0.072 \\
\hline $\mathrm{SC} / \mathrm{CSH}$ & 0.226 & 0.171 & 0.209 & 0.146 & $\mathrm{CH} 8$ & 4.773 & 4.811 & 4.770 & 4.786 \\
\hline $\mathrm{SC} / \mathrm{CCS}$ & 0.208 & 0.221 & 0.209 & 0.158 & $\mathrm{CH} 8 / \mathrm{CH} 9$ & 0.048 & 0.048 & 0.048 & 0.048 \\
\hline $\mathrm{SC} / \mathrm{SCH} 5$ & 0.177 & 0.133 & 0.178 & 0.185 & $\mathrm{CH} 8 / \mathrm{CCS}$ & -0.021 & -0.033 & -0.015 & -0.016 \\
\hline $\mathrm{SC} / \mathrm{SCH} 6$ & 0.178 & 0.182 & 0.167 & 0.187 & $\mathrm{CH} 8 / \mathrm{CCH} 6$ & 0.034 & 0.036 & 0.026 & 0.032 \\
\hline $\mathrm{SC} / \mathrm{CCH} 5$ & -0.193 & -0.187 & -0.198 & -0.186 & CH8/CCH9 & -0.066 & -0.065 & -0.067 & -0.065 \\
\hline $\mathrm{SC} / \mathrm{HCH} 6$ & -0.180 & -0.180 & -0.176 & -0.154 & $\mathrm{CH} 8 / \mathrm{CCH} 7$ & -0.067 & -0.065 & -0.067 & -0.068 \\
\hline $\mathrm{SC} / \mathrm{CCH} 6$ & -0.192 & -0.173 & -0.181 & -0.186 & $\mathrm{CH} 8 / \mathrm{CCH} 8$ & 0.050 & 0.049 & 0.052 & 0.054 \\
\hline $\mathrm{SC} / \mathrm{CCH} 9$ & -0.027 & -0.031 & -0.028 & -0.018 & $\mathrm{CH} 8 / \mathrm{HCHa}$ & -0.070 & -0.068 & -0.072 & -0.070 \\
\hline $\mathrm{SC} / \mathrm{CCH} 7$ & 0.058 & 0.065 & 0.063 & 0.045 & $\mathrm{CH} 8 / \mathrm{HCHb}$ & 0.076 & 0.072 & 0.077 & 0.072 \\
\hline $\mathrm{CC}$ & 4.379 & 4.383 & 4.380 & 4.369 & $\mathrm{CH} 8 / \mathrm{HCHc}$ & 0.078 & 0.079 & 0.080 & 0.078 \\
\hline $\mathrm{CC} / \mathrm{CH} 5$ & 0.070 & 0.075 & 0.080 & 0.071 & CH9 & 4.771 & 4.751 & 4.808 & 4.782 \\
\hline $\mathrm{CC} / \mathrm{CH} 6$ & 0.070 & 0.077 & 0.074 & 0.071 & $\mathrm{CH} 9 / \mathrm{CCS}$ & -0.021 & -0.017 & -0.033 & -0.015 \\
\hline $\mathrm{CC} / \mathrm{CH} 7$ & 0.075 & 0.077 & 0.076 & 0.073 & $\mathrm{CH} 9 / \mathrm{CCH} 5$ & 0.034 & 0.031 & 0.036 & 0.031 \\
\hline $\mathrm{CC} / \mathrm{CH} 8$ & 0.074 & 0.065 & 0.074 & 0.076 & CH9/CCH9 & 0.050 & 0.049 & 0.047 & 0.055 \\
\hline $\mathrm{CC} / \mathrm{CH} 9$ & 0.074 & 0.073 & 0.065 & 0.077 & $\mathrm{CH} 9 / \mathrm{CCH} 7$ & -0.067 & -0.067 & -0.064 & -0.068 \\
\hline $\mathrm{CC} / \mathrm{CSH}$ & -0.049 & -0.026 & 0.021 & 0.053 & СH9/CCH8 & -0.066 & -0.068 & -0.065 & -0.066 \\
\hline $\mathrm{CC} / \mathrm{CCS}$ & 0.149 & 0.139 & 0.144 & 0.192 & $\mathrm{CH} 9 / \mathrm{HCHa}$ & 0.077 & 0.080 & 0.073 & 0.073 \\
\hline $\mathrm{CC} / \mathrm{SCH} 5$ & -0.153 & -0.150 & -0.145 & -0.157 & $\mathrm{CH} / \mathrm{HCHb}$ & -0.070 & -0.072 & -0.068 & -0.071 \\
\hline $\mathrm{CC} / \mathrm{SCH} 6$ & -0.152 & -0.143 & -0.148 & -0.157 & $\mathrm{CH9} / \mathrm{HCHc}$ & 0.078 & 0.081 & 0.080 & 0.079 \\
\hline $\mathrm{CC} / \mathrm{CCH} 5$ & 0.137 & 0.141 & 0.132 & 0.137 & $\mathrm{CSH}$ & 0.850 & 0.815 & 0.824 & 0.794 \\
\hline $\mathrm{CC} / \mathrm{HCH} 6$ & -0.143 & -0.142 & -0.147 & -0.156 & $\mathrm{CSH} / \mathrm{CCS}$ & -0.051 & -0.061 & 0.062 & 0.176 \\
\hline $\mathrm{CC} / \mathrm{CCH} 6$ & 0.137 & 0.126 & 0.143 & 0.136 & CSH/SCH5 & 0.058 & 0.154 & 0.061 & -0.060 \\
\hline $\mathrm{CC} / \mathrm{CCH9}$ & 0.161 & 0.159 & 0.170 & 0.156 & $\mathrm{CSH} / \mathrm{SCH} 6$ & 0.056 & -0.058 & -0.067 & -0.058 \\
\hline $\mathrm{CC} / \mathrm{CCH} 7$ & 0.113 & 0.100 & 0.099 & 0.124 & $\mathrm{CSH} / \mathrm{CCH} 7$ & -0.013 & -0.006 & 0.019 & 0.038 \\
\hline $\mathrm{CC} / \mathrm{CCH} 8$ & 0.161 & 0.169 & 0.164 & 0.156 & $\mathrm{CCS}$ & 0.768 & 0.737 & 0.740 & 0.745 \\
\hline $\mathrm{CC} / \mathrm{HCHa}$ & -0.154 & -0.154 & -0.147 & -0.153 & CCS/SCH5 & -0.150 & -0.145 & -0.156 & -0.142 \\
\hline $\mathrm{CC} / \mathrm{HCHb}$ & -0.154 & -0.146 & -0.154 & -0.153 & $\mathrm{CCS} / \mathrm{SCH} 6$ & -0.149 & -0.141 & -0.133 & -0.143 \\
\hline $\mathrm{CC} / \mathrm{HCHc}$ & -0.143 & -0.144 & -0.146 & -0.145 & $\mathrm{CCS} / \mathrm{CCH} 5$ & -0.177 & -0.175 & -0.179 & -0.155 \\
\hline CH5 & 4.855 & 4.829 & 4.861 & 4.848 & CCS/HCH6 & -0.148 & -0.145 & -0.149 & -0.151 \\
\hline $\mathrm{CH} 5 / \mathrm{CH} 6$ & 0.058 & 0.051 & 0.051 & 0.056 & $\mathrm{CCS} / \mathrm{CCH} 6$ & -0.176 & -0.171 & -0.153 & -0.157 \\
\hline $\mathrm{CH} 5 / \mathrm{CCS}$ & -0.052 & -0.057 & -0.046 & -0.051 & CCS/CCH 9 & -0.034 & -0.036 & -0.041 & -0.036 \\
\hline CH5/SCH5 & 0.008 & 0.052 & 0.005 & 0.003 & $\mathrm{CCS} / \mathrm{CCH} 7$ & 0.085 & 0.091 & 0.093 & 0.091 \\
\hline CH5/SCH6 & -0.044 & -0.059 & -0.052 & -0.045 & $\mathrm{CCS} / \mathrm{CCH} 8$ & -0.035 & -0.041 & -0.040 & -0.036 \\
\hline $\mathrm{CH} 5 / \mathrm{CCH} 5$ & 0.056 & 0.055 & 0.064 & 0.057 & $\mathrm{CCS} / \mathrm{CS} \mathrm{t}$ & -0.000 & 0.000 & 0.045 & -0.002 \\
\hline CH5/HCH6 & 0.098 & 0.090 & 0.091 & 0.094 & SCH5 & 0.544 & 0.549 & 0.540 & 0.523 \\
\hline CH5/CCH6 & -0.059 & -0.066 & -0.058 & -0.058 & $\mathrm{SCH} 5 / \mathrm{SCH} 6$ & -0.115 & -0.110 & -0.105 & -0.099 \\
\hline CH6 & 4.856 & 4.841 & 4.868 & 4.847 & SCH5/CCH5 & -0.066 & -0.063 & -0.069 & -0.083 \\
\hline $\mathrm{CH} 6 / \mathrm{CSH}$ & 0.014 & -0.010 & -0.040 & -0.002 & $\mathrm{SCH} 5 / \mathrm{HCH} 6$ & -0.080 & -0.071 & -0.074 & -0.076 \\
\hline CH6/CCS & -0.052 & -0.047 & -0.049 & -0.051 & $\mathrm{SCH} 5 / \mathrm{CCH} 6$ & -0.121 & -0.126 & -0.122 & -0.118 \\
\hline CH6/SCH5 & -0.044 & -0.052 & -0.050 & -0.045 & $\mathrm{SCH} 5 / \mathrm{CS} \mathrm{t}$ & 0.045 & -0.011 & -0.036 & 0.004 \\
\hline $\mathrm{CH} 6 / \mathrm{CCH} 5$ & -0.059 & -0.057 & -0.057 & -0.058 & SCH6 & 0.543 & 0.526 & 0.526 & 0.524 \\
\hline $\mathrm{CH} 6 / \mathrm{HCH} 6$ & 0.098 & 0.092 & 0.094 & 0.094 & $\mathrm{SCH} 6 / \mathrm{CCH} 5$ & -0.121 & -0.120 & -0.120 & -0.118 \\
\hline $\mathrm{CH} 6 / \mathrm{CCH} 6$ & 0.056 & 0.063 & 0.058 & 0.057 & $\mathrm{SCH} 6 / \mathrm{HCH} 6$ & -0.080 & -0.089 & -0.080 & -0.076 \\
\hline $\mathrm{CH} 7$ & 4.747 & 4.719 & 4.724 & 4.762 & $\mathrm{SCH} 6 / \mathrm{CCH} 6$ & -0.066 & -0.064 & -0.076 & -0.083 \\
\hline $\mathrm{CH} 7 / \mathrm{CH} 8$ & 0.049 & 0.046 & 0.050 & 0.048 & $\mathrm{SCH} 6 / \mathrm{CS} \mathrm{t}$ & -0.045 & 0.011 & -0.003 & -0.003 \\
\hline $\mathrm{CH} 7 / \mathrm{CH} 9$ & 0.049 & 0.051 & 0.046 & 0.048 & $\mathrm{CCH} 5$ & 0.543 & 0.555 & 0.556 & 0.547 \\
\hline $\mathrm{CH} 7 / \mathrm{CCS}$ & 0.033 & 0.043 & 0.044 & 0.031 & $\mathrm{CCH} 5 / \mathrm{HCH} 6$ & -0.074 & -0.061 & -0.074 & -0.081 \\
\hline
\end{tabular}


Table V (Continued)

\begin{tabular}{|c|c|c|c|c|c|c|c|c|c|}
\hline \multirow{2}{*}{$\begin{array}{c}\text { Force } \\
\text { Constant }^{a}\end{array}$} & \multicolumn{4}{|c|}{ Value $^{b}$} & \multirow{2}{*}{$\begin{array}{c}\text { Force } \\
\text { Constant }^{\mathrm{a}}\end{array}$} & \multicolumn{4}{|c|}{ Value $^{b}$} \\
\hline & $\mathrm{C}$ & $\mathrm{G}$ & $\mathbf{S}$ & $\mathrm{T}$ & & $\mathrm{C}$ & $\mathrm{G}$ & $\mathrm{S}$ & $\mathrm{T}$ \\
\hline $\mathrm{CCH} 5 / \mathrm{CCH} 6$ & -0.116 & -0.126 & -0.120 & -0.113 & $\mathrm{CCH} 7 / \mathrm{CCH} 8$ & -0.126 & -0.126 & -0.125 & -0.126 \\
\hline CCH5/CCH9 & 0.087 & 0.087 & 0.089 & 0.089 & $\mathrm{CCH} 7 / \mathrm{HCHa}$ & -0.084 & -0.087 & -0.086 & -0.085 \\
\hline $\mathrm{CCH} 5 / \mathrm{CCH} 7$ & -0.037 & -0.039 & -0.041 & -0.038 & $\mathrm{CCH} 7 / \mathrm{HCHb}$ & -0.084 & -0.085 & -0.087 & -0.085 \\
\hline $\mathrm{CCH} 5 / \mathrm{CCH} 8$ & -0.040 & -0.038 & -0.038 & -0.040 & $\mathrm{CCH} 7 / \mathrm{HCHc}$ & -0.099 & -0.096 & -0.095 & -0.097 \\
\hline $\mathrm{HCH} 6$ & 0.490 & 0.482 & 0.475 & 0.465 & $\mathrm{CCH} 8$ & 0.524 & 0.524 & 0.528 & 0.527 \\
\hline $\mathrm{HCH} 6 / \mathrm{CCH} 6$ & -0.075 & -0.078 & -0.073 & -0.081 & $\mathrm{CCH} 8 / \mathrm{HCHa}$ & -0.099 & -0.100 & -0.098 & -0.099 \\
\hline $\mathrm{CCH} 6$ & 0.543 & 0.530 & 0.534 & 0.548 & $\mathrm{CCH} 8 / \mathrm{HCHb}$ & -0.094 & -0.090 & -0.094 & -0.094 \\
\hline $\mathrm{CCH} 6 / \mathrm{CCH} 9$ & -0.040 & -0.038 & -0.039 & -0.040 & $\mathrm{CCH} 8 / \mathrm{HCHc}$ & -0.089 & -0.092 & -0.092 & -0.090 \\
\hline $\mathrm{CCH} 6 / \mathrm{CCH} 7$ & -0.037 & -0.038 & -0.037 & -0.038 & $\mathrm{HCHa}$ & 0.454 & 0.453 & 0.447 & 0.452 \\
\hline $\mathrm{CCH} 6 / \mathrm{CCH} 8$ & 0.087 & 0.087 & 0.088 & 0.089 & $\mathrm{HCHa} / \mathrm{HCHb}$ & -0.079 & $-0,081$ & -0.080 & -0.078 \\
\hline ССH9 & 0.524 & 0.525 & 0.525 & 0.527 & $\mathrm{HCHa} / \mathrm{HCHc}$ & -0.085 & -0.082 & -0.082 & -0.084 \\
\hline $\mathrm{CCH} 9 / \mathrm{CCH} 7$ & -0.126 & -0.125 & -0.127 & -0.125 & $\mathrm{HCHb}$ & 0.454 & 0.448 & 0.452 & 0.452 \\
\hline СCH9/CCH8 & -0.128 & -0.128 & -0.128 & -0.129 & $\mathrm{HCHb} / \mathrm{HCHc}$ & -0.085 & -0.083 & -0.081 & -0.084 \\
\hline СCH9/HCHa & -0.094 & -0.093 & -0.090 & -0.095 & $\mathrm{HCHc}$ & 0.451 & 0.451 & 0.450 & 0.450 \\
\hline $\mathrm{CCH} 9 / \mathrm{HCHb}$ & -0.099 & -0.098 & -0.099 & -0.099 & $\mathrm{CSt}$ & -0.029 & 0.035 & -0.024 & 0.028 \\
\hline СCH9/HCHc & -0.089 & -0.090 & -0.093 & -0.090 & $\mathrm{CCt}$ & 0.116 & 0.098 & 0.098 & 0.092 \\
\hline $\mathrm{CCH} 7$ & 0.515 & 0.510 & 0.511 & 0.513 & & & & & \\
\hline
\end{tabular}

${ }^{a} \mathrm{XY}: \mathrm{X}-\mathrm{Y}$ stretch; XYZ: X-Y - Z bend; t: torsion. HCHa: H7C4H9; HCHb: H7C4H8; HCHc: H8C4H9.

${ }^{\mathrm{b}}$ Values included only if force constant for one conformer $\geq 0.03$.

group, taken from the crystal structure of glutathione. ${ }^{37}$

Since it is not possible to know a priori which of the many conformers of 3 TNMP may be most prevalent in aqueous solution, we have attempted to answer this question spectroscopically. The conformation of 3TNMP depends on three dihedral angles, ${ }^{N C C}{ }^{\alpha} \mathrm{C}^{\beta}(\psi), \mathrm{CC}^{\alpha} \mathrm{C}^{\beta} \mathrm{S}\left(\chi^{1}\right)$, and $\mathrm{C}^{\alpha} \mathrm{C}^{\beta} \mathrm{SH}\left(\chi^{2}\right)$ ( see Figure 2). We have, by analogy with the observations for ET and $1 \mathrm{PT}$, set $\chi^{2}=\mathrm{G}$. We then examined the normal modes of the 15 conformers obtained by setting $\chi^{1}=T, G$, and $G^{\prime}$ and $\psi=S^{\prime}, G^{\prime}, G, S$, and $\mathrm{T}$ ( the $\psi=\mathrm{C}$ structure is obviously of high energy). Using an initial force field (see below), we did a least squares refinement of scale factors for each conformer to the observed non- $\mathrm{CH}$ s $\mathrm{NH}, \mathrm{SH}$ and (with half the weight) ND, SD frequencies, and examined the goodness of fit using several criteria. We assume that, in general, a relatively complete starting force field will refine most satisfactorily for the conformer $(\mathrm{s})$ that actually gives rise to the observed frequencies. Such selectivity seems to be indicated here.

The initial force field was obtained by combining the ab initio force field of hydrogen-bonded $\mathrm{NMA}^{33}$ with our ab initio force field for ET (except that empirical values ${ }^{34}$ were used for $\mathrm{CC} t$ and $\mathrm{NC} t$ ). Since both of these molecules have a $\mathrm{C}^{\alpha} \mathrm{H}_{3}$ rather than a $\mathrm{C}^{\alpha} \mathrm{H}_{2}$ group, it was necessary to modify the force constants at the $\mathrm{C}^{\alpha}$ atom, where the two molecules "merge." This was done as follows. First, diagonal force constants relating to the merged region were retained from each force field, for example, $f\left(\mathrm{C}^{\beta} \mathrm{C}^{\alpha} \mathrm{H}\right)$ from the $\mathrm{ET}$ force field and $f\left(\mathrm{CC}^{\alpha} \mathrm{H}\right)$ from the NMA force field. For $f\left(\mathrm{C}^{\alpha} \mathrm{H}\right)$ and $f\left(\mathrm{HC}^{\alpha} \mathrm{H}\right)$ the ET values were initially used, and an appropriate starting value was taken for $f\left(\mathrm{CC}^{\alpha} \mathrm{C}^{\beta}\right) .{ }^{36}$ Of course, common force constants in each force field were required to have the same values; thus, what was the corresponding $f\left(\mathrm{C}^{*} \mathrm{H}\right)$ in the NMA force field must take the value of $f\left(\mathrm{C}^{\alpha} \mathrm{C}^{\beta}\right)$ of the ET force field and what was the $f\left(\mathrm{C}^{\alpha} \mathrm{H}\right)$ of ET must take the value of $f\left(\mathrm{CC}^{\alpha}\right)$ of NMA. Second, although all off-diagonal terms in each force field were retained, it was assumed that there were no interaction terms between the two parts; thus, for example, $f\left(\mathrm{NCC}^{\alpha}, \mathrm{CC}^{\alpha} \mathrm{C}^{\beta}\right)$ would be included (with an initial value from the NMA force field) but not $f\left(\mathrm{NCC}^{\alpha}, \mathrm{C}^{\alpha} \mathrm{C}^{\beta} \mathrm{S}\right)$. Relevant off-diagonal constants not in either force field were approximated by using the standard scaling procedure $^{35}$ on the corresponding adjusted diagonal scale factors and applying the resulting scale factor to the appropriate off-diagonal constant in the ET or NMA force fields. Third, hydrogen-bond force constants were chosen from $\mathrm{NMA}^{33}$ to give approximate $\mathrm{H} \cdots \mathrm{O}$ s frequencies (below $\sim 150 \mathrm{~cm}^{-1}$ ) in order to incorporate this effect, without expecting any accuracy in these modes since no experimental 
Table VI Observed and Calculated Frequencies (in $\mathrm{cm}^{-1}$ ) of ET

\begin{tabular}{|c|c|c|c|c|c|c|}
\hline \multicolumn{2}{|c|}{$\nu(\mathrm{obs})^{\mathrm{a}}$} & \multicolumn{2}{|c|}{$\nu$ (calc) } & \multirow[b]{2}{*}{$I(\mathrm{ir})^{\mathrm{b}}$} & \multirow[b]{2}{*}{$I(\mathrm{R})^{\mathrm{b}}$} & \multirow[b]{2}{*}{$\mathrm{PED}^{\mathrm{c}}$} \\
\hline Gas & Cond & $\nu(\mathrm{G})$ & $\nu(\mathrm{T})$ & & & \\
\hline & 2980 & 2988 & & 24.9 & 11.0 & $\mathrm{CH}_{2}$ as $(80) \mathrm{CH}_{3}$ as2(11) \\
\hline & & & 2993 & 25.4 & 19.7 & $\mathrm{CH}_{2}$ as $(88)$ \\
\hline \multirow[t]{2}{*}{$2971 \mathrm{vw}$} & 2966 & 2961 & & 6.7 & 98.7 & $\mathrm{CH}_{3} \operatorname{as1}(67) \mathrm{CH}_{2}$ as(17) $\mathrm{CH}_{3}$ as2(12) \\
\hline & & & 2961 & 28.8 & 72.4 & $\mathrm{CH}_{3}$ as1(75) $\mathrm{CH}_{2} \operatorname{ss}(17)$ \\
\hline \multirow[t]{2}{*}{$2946 v s$} & & 2950 & & 31.6 & 78.5 & $\mathrm{CH}_{3}$ as2(54) $\mathrm{CH}_{2} \mathrm{ss}(38)$ \\
\hline & & & 2958 & 4.8 & 106.0 & $\mathrm{CH}_{3}$ as2(78) $\mathrm{CH}_{2}$ as(12) $\mathrm{CH}_{3}$ as1(10) \\
\hline \multirow[t]{2}{*}{$2940 \mathrm{vs}$} & 2931 & 2937 & & 7.3 & 109.5 & $\mathrm{CH}_{2} \mathrm{ss}(60) \mathrm{CH}_{3}$ as $2(24) \mathrm{CH}_{3}$ as $1(15)$ \\
\hline & & & 2942 & 14.9 & 105.2 & $\mathrm{CH}_{2} \mathrm{ss}(83) \mathrm{CH}_{3}$ as1(13) \\
\hline \multirow[t]{2}{*}{$2886 \mathrm{~m}$} & 2876 & 2895 & & 23.6 & 100.6 & $\mathrm{CH}_{3} \operatorname{ss}(97)$ \\
\hline & & & 2902 & 19.3 & 97.2 & $\mathrm{CH}_{3} \mathrm{ss}(100)$ \\
\hline $2594 \mathrm{~s}$ & 2561 & 2594 & & 13.6 & 117.0 & $\mathrm{SH} s(100)$ \\
\hline \multirow[t]{2}{*}{$2603 w$} & & & 2597 & 17.0 & 148.7 & $\mathrm{SH} \mathrm{s}(100)$ \\
\hline & & $(1450$ & & 4.1 & 16.6 & $\mathrm{CH}_{3}$ ab2(88) \\
\hline \multirow[t]{7}{*}{$1450 \mathrm{w}$} & 1451 & & 1453 & 4.3 & 16.6 & $\mathrm{CH}_{3} \mathrm{ab2}(72) \mathrm{CH}_{3} \mathrm{abl}(21)$ \\
\hline & & l 1447 & & 10.7 & 22.7 & $\mathrm{CH}_{3}$ ab1 (87) \\
\hline & & & 1449 & 9.9 & 25.0 & $\mathrm{CH}_{3} \operatorname{ab1}(71) \mathrm{CH}_{3} \mathrm{ab} 2(21)$ \\
\hline & 1434 & 1434 & & 6.1 & 21.6 & $\mathrm{CH}_{2} \mathrm{~b}(99)$ \\
\hline & & & 1443 & 6.7 & 18.7 & $\mathrm{CH}_{2} \mathrm{~b}(100)$ \\
\hline & 1377 & 1375 & & 6.0 & 3.2 & $\mathrm{CH}_{3} \mathrm{sb}(105)$ \\
\hline & & & 1375 & 6.8 & 2.9 & $\mathrm{CH}_{3} \mathrm{sb}(106)$ \\
\hline \multirow[t]{4}{*}{$1275 w$} & 1272 & 1279 & & 12.9 & 2.0 & $\mathrm{CH}_{2} \mathrm{w}(92)$ \\
\hline & & & 1278 & 32.4 & 1.9 & $\mathrm{CH}_{2} \mathrm{w}(94)$ \\
\hline & 1250 & 1255 & & 4.3 & 12.7 & $\mathrm{CH}_{2} \mathrm{tw}(63) \mathrm{CH}_{3} \mathrm{r} 1(10)$ \\
\hline & & & 1246 & 0.6 & 10.8 & $\mathrm{CH}_{2} \mathrm{tw}(57) \mathrm{CH}_{3} \mathbf{r} 1(15)$ \\
\hline \multirow[t]{2}{*}{$1098 w$} & 1095 & 1100 & & 13.1 & 11.9 & $\mathrm{CH}_{3} \mathbf{r 1}(30) \mathrm{CSH} b(23) \mathrm{CH}_{2} \mathrm{r}(15)$ \\
\hline & & & 1094 & 3.9 & 13.9 & $\mathrm{CC} \mathrm{s}(28) \mathrm{CH}_{3} \mathbf{r} 2(26) \mathrm{CSH}$ b(19) \\
\hline \multirow[t]{2}{*}{$1045 \mathrm{w}$} & 1052 & 1048 & & 3.4 & 5.0 & $\mathrm{CC} \mathrm{s}(39) \mathrm{CH}_{3} \mathbf{r} 2(38)$ \\
\hline & & & 1021 & 0.0 & 6.5 & $\mathrm{CH}_{2} \mathrm{tw}(43) \mathrm{CH}_{3} \mathrm{r} 1(27) \mathrm{CH}_{2} \mathrm{r}(21) \mathrm{CH}_{3} \mathrm{r} 2(10)$ \\
\hline \multirow[t]{2}{*}{$985 \mathrm{w}$} & 971 & 985 & & 4.8 & 8.2 & $\mathrm{CC} \mathrm{s}(49) \mathrm{CH}_{3} \mathrm{r} 2(28)$ \\
\hline & & & 990 & 6.4 & 6.8 & $\mathrm{CC} \mathrm{s(56)} \mathrm{CH}_{3} \mathrm{r} 2(19)$ \\
\hline $870 \mathrm{w}$ & 868 & 870 & & 12.0 & 7.4 & $\mathrm{CSH} \mathrm{b}(57) \mathrm{CH}_{3} \mathrm{r} 1(34) \mathrm{CH}_{2}$ tw $(22)$ \\
\hline $855 w$ & & & 859 & 1.7 & 12.7 & $\mathrm{CSH} \mathrm{b}(77) \mathrm{CC} \mathrm{s}(13) \mathrm{CH}_{3} \mathrm{r} 2(11)$ \\
\hline \multirow[t]{2}{*}{$736 \mathrm{w}$} & 738 & 718 & & 2.5 & 3.0 & $\mathrm{CH}_{2}$ r(72) CSH b(17) $\mathrm{CH}_{3}$ r1(10) \\
\hline & 781 & & 770 & 5.7 & 0.4 & $\mathrm{CH}_{2} \mathrm{r}(73) \mathrm{CH}_{3} \mathrm{rl}(27)$ \\
\hline $662 \mathrm{~m}$ & 660 & 662 & & 5.1 & 25.3 & $\operatorname{CS} s(89)$ \\
\hline $675 \mathrm{w}$ & & & 672 & 1.9 & 30.0 & $\operatorname{CS~s}(92)$ \\
\hline \multirow[t]{2}{*}{$330 \mathrm{w}$} & 333 & 330 & & 1.2 & 2.0 & $\operatorname{CCS} d(88)$ \\
\hline & & & 308 & 2.8 & 0.7 & CCS d $(95)$ \\
\hline $246 v v w$ & & 246 & & 6.1 & 2.2 & $\mathrm{CC} t(90)$ \\
\hline 232 vvw & & & 240 & 2.8 & 2.1 & $\mathrm{CCt}(86)$ \\
\hline $191 w^{d}$ & & 191 & & 18.8 & 7.9 & $\operatorname{CS} t(95)$ \\
\hline $157 \mathrm{vvw}^{e}$ & & & 166 & 22.1 & 9.6 & $\operatorname{Cst}(98) \operatorname{CC} t(14)$ \\
\hline
\end{tabular}

${ }^{a}$ Gas-phase Raman frequencies: Ref. 16, except for 2594 and 2603, from Ref. 10. Condensed-phase frequencies (average of liquid and glass phases): Ref. 9 .

${ }^{\mathrm{b}} I(\mathrm{ir})=$ calculated ir intensity, $I(\mathrm{R})=$ calculated Raman intensity.

${ }^{c}$ Contributions to potential energy distribution $\geq 10$. s: Stretch; ss: symmetric stretch; as: antisymmetric stretch; b: bend; sb: symmetric bend; ab: antisymmetric bend; d: deformation; w: wag; tw: twist; $r$ : rock; t: torsion.

${ }^{d}$ Given as $190 \mathrm{~cm}^{-1}$ in Ref. 14 and $193 \mathrm{~cm}^{-1}$ in Ref. 15.

Given as $158 \mathrm{~cm}^{-1}$ in Refs. 14 and 15.

data are available (in fact, we do not report such modes).

The calculations showed that a number of modes were particularly sensitive to conformation, with frequencies varying by up to $\sim 70 \mathrm{~cm}^{-1}$ between conformers. In Table IX we present various measures of the goodness of fit between the observed frequencies of 3TNMP and the calculated frequen- 
Table VII Observed and Calculated Frequencies (in $\mathrm{cm}^{-1}$ ) of ET-SD

\begin{tabular}{|c|c|c|c|}
\hline \multirow[b]{2}{*}{$\nu(\mathrm{obs})^{\mathrm{a}}$} & \multicolumn{2}{|c|}{$\nu($ calc $)$} & \multirow[b]{2}{*}{$\mathrm{PED}^{\mathbf{b}}$} \\
\hline & $\nu(\mathrm{G})$ & $\nu(\mathrm{T})$ & \\
\hline & 2988 & & $\mathrm{CH}_{2}$ as $(80) \mathrm{CH}_{3}$ as $2(11)$ \\
\hline & & 2993 & $\mathrm{CH}_{2}$ as $(88)$ \\
\hline \multirow[t]{2}{*}{$2971 \mathrm{vw}$} & 2961 & & $\mathrm{CH}_{3}$ as1(87) $\mathrm{CH}_{2}$ as (18) $\mathrm{CH}_{3}$ as2(12) \\
\hline & & 2961 & $\mathrm{CH}_{3}$ as1(75) $\mathrm{CH}_{2} \mathrm{ss}(16)$ \\
\hline $2945 \mathrm{vs}$ & 2950 & & $\mathrm{CH}_{3}$ as2(54) $\mathrm{CH}_{2} \mathrm{ss}(38)$ \\
\hline $2951 \mathrm{vw}$ & & 2958 & $\mathrm{CH}_{3}$ as2(78) $\mathrm{CH}_{2}$ as(12) $\mathrm{CH}_{3}$ as1(10) \\
\hline \multirow[t]{2}{*}{$2940 v s$} & 2937 & & $\mathrm{CH}_{2} \mathrm{ss}(60) \mathrm{CH}_{3}$ as $2(24) \mathrm{CH}_{3}$ as $1(15)$ \\
\hline & & 2942 & $\mathrm{CH}_{2} \mathrm{ss}(83) \mathrm{CH}_{3}$ as $1(13)$ \\
\hline \multirow[t]{2}{*}{$2882 \mathrm{~m}$} & 2895 & & $\mathrm{CH}_{3} \mathrm{ss}(97)$ \\
\hline & & 2902 & $\mathrm{CH}_{3} \mathrm{ss}(100)$ \\
\hline $1881 \mathrm{~m}$ & 1866 & & $\mathrm{SD} s(100)$ \\
\hline \multirow[t]{2}{*}{ 1886sh } & & 1868 & $\mathrm{SD} \mathrm{s}(100)$ \\
\hline & $(1451$ & & $\mathrm{CH}_{3} \mathrm{ab} 2(87)$ \\
\hline \multirow[t]{6}{*}{$1450 w$} & $\left\{\begin{array}{l}1447 \\
144\end{array}\right.$ & 1453 & $\begin{array}{l}\mathrm{CH}_{3} \text { ab2(72) } \mathrm{CH}_{3} \text { ab1(21) } \\
\mathrm{CH}_{3} \text { ab1(87) }\end{array}$ \\
\hline & & 1449 & $\mathrm{CH}_{3}$ ab1(71) $\mathrm{CH}_{3}$ ab2(21) \\
\hline & 1434 & & $\mathrm{CH}_{2} \mathbf{b}(99)$ \\
\hline & & 1443 & $\mathrm{CH}_{2} \mathrm{~b}(100)$ \\
\hline & 1375 & & $\mathrm{CH}_{3} \mathrm{sb}(105)$ \\
\hline & & 1375 & $\mathrm{CH}_{3} \mathrm{sb}(106)$ \\
\hline \multirow[t]{4}{*}{$1271 w$} & 1277 & & $\mathrm{CH}_{2} \mathrm{w}(94)$ \\
\hline & & 1275 & $\mathrm{CH}_{2} \mathrm{w}(95)$ \\
\hline & 1253 & & $\mathrm{CH}_{2}$ tw(63) $\mathrm{CH}_{3} \mathrm{r} 1(12)$ \\
\hline & & 1246 & $\mathrm{CH}_{2} \mathrm{tw}(57) \mathrm{CH}_{3} \mathrm{r} 1(15)$ \\
\hline \multirow[t]{2}{*}{$1069 w$} & 1064 & & $\mathrm{CC} \mathrm{s}(31) \mathrm{CH}_{3} \mathrm{r} 1(29)$ \\
\hline & & 1067 & $\mathrm{CC} \mathrm{s}(36) \mathrm{CH}_{3} \mathrm{r} 2(32) \mathrm{CH}_{3} \mathrm{r} 1(11)$ \\
\hline \multirow[t]{2}{*}{$1046 \mathrm{w}$} & 1042 & & $\mathrm{CH}_{3} \mathrm{r} 2(30) \mathrm{CH}_{2} \mathrm{tw}(23) \mathrm{CC} \mathrm{s}(16) \mathrm{CH}_{2} \mathrm{r}(15)$ \\
\hline & & 1021 & $\mathrm{CH}_{2}$ tw(43) $\mathrm{CH}_{3} \mathrm{r} 1(28) \mathrm{CH}_{2} \mathbf{r}(21) \mathrm{CH}_{3} \mathbf{r} 2(10)$ \\
\hline \multirow[t]{4}{*}{$978 w$} & 984 & & $\mathrm{CC} \mathrm{s}(48) \mathrm{CH}_{3} \mathrm{r} 2(26)$ \\
\hline & & 990 & $\mathrm{CC} \mathrm{s}(58) \mathrm{CH}_{3} \mathrm{r} 2(18)$ \\
\hline & 779 & & $\mathrm{CH}_{2} \mathrm{r}(48) \mathrm{CH}_{3} \mathrm{r} 1(33) \mathrm{CSD} b(15)$ \\
\hline & & 769 & $\mathrm{CH}_{2} \mathbf{r}(73) \mathrm{CH}_{3} \mathbf{r} 1(28)$ \\
\hline $676 \mathrm{~m}$ & 670 & & $\operatorname{CS~s}(89) \operatorname{CCS} d(10)$ \\
\hline $696 w$ & & 704 & $\mathrm{CS} \mathrm{s}(63) \mathrm{CSD} b(33) \mathrm{CH}_{3} \mathrm{r} 2(11)$ \\
\hline \multirow[t]{2}{*}{$625 w$} & 610 & & $\mathrm{CSD} \mathrm{b}(80) \mathrm{CH}_{2} \mathbf{r}(31)$ \\
\hline & & 620 & $\operatorname{CSD} b(56) \operatorname{CS~s}(32)$ \\
\hline $325 w$ & 326 & & $\operatorname{CCS} d(87)$ \\
\hline $301 \mathrm{vvw}$ & & 302 & $\operatorname{CCS} d(95)$ CSD b(13) \\
\hline $250 \mathrm{vw}$ & 244 & & $\operatorname{CCt}(93)$ \\
\hline $232 v w$ & & 238 & $\mathrm{CC} \mathrm{t}(92)$ \\
\hline $150 w^{c}$ & 144 & & $\operatorname{CS} t(99)$ \\
\hline $136 w^{d}$ & & 125 & $\operatorname{CS} t(101)$ \\
\hline
\end{tabular}

${ }^{a}$ Gas-phase Raman frequencies from Ref. 16.

${ }^{b}$ Contributions to potential energy distribution $\geq 10$. s: Stretch; ss: symmetric stretch; as: antisymmetric stretch; b: bend; sb: symmetric bend; ab: antisymmetric bend; d: deformation; w: wag; tw: twist, r: rock; t: torsion.

${ }^{\mathrm{c}}$ Given as $149 \mathrm{~cm}^{-1}$ in Ref. 15 .

${ }^{\mathrm{d}}$ Given as $125 \mathrm{~cm}^{-1}$ in Ref. 15 .

cies obtained from a least-squares refinement of scale factors for each conformer. Since the CS s frequency was well reproduced for ET and 1PT, we expect that it should be comparably well predicted in 3 TNMP. Thus, the TGG and TG'G conformers, with discrepancies of 84 and $91 \mathrm{~cm}^{-1}$, respectively, are unacceptable possibilities for the actually existing structure $(\mathrm{s})$. A similar potential conclusion about S"TG, G"TG, GTG, STG, and TTG is strengthened when we examine the average devia- 
Table VIII Observed and Calculated Frequencies $\left(\right.$ in $\mathrm{cm}^{-1}$ ) of 1PT

\begin{tabular}{|c|c|c|c|c|c|c|c|c|}
\hline \multicolumn{3}{|c|}{$\nu(\text { obs })^{\mathrm{a}}$} & \multicolumn{5}{|c|}{$\nu($ calc $)$} & \multirow[b]{2}{*}{ Mode $^{b}$} \\
\hline$\nu(\mathrm{g})$ & $\nu\left(l_{R}\right)$ & $\nu\left(\mathrm{l}_{\mathrm{L}}\right)$ & $\mathrm{TG}$ & GG & TT & $\mathrm{G}^{\prime} \mathrm{G}$ & GT & \\
\hline & & & 2985 & 2984 & 2991 & 2985 & 2992 & $\mathrm{C}^{\beta} \mathrm{H}_{2}$ as \\
\hline & & & 2955 & 2955 & 2955 & 2955 & 2955 & $\mathrm{CH}_{3}$ as2 \\
\hline \multirow[t]{5}{*}{$2950 \mathrm{bd}$} & $2950 \mathrm{bd}$ & $2950 \mathrm{bd}$ & 2955 & 2955 & 2955 & 2955 & 2955 & $\mathrm{CH}_{3}$ as 1 \\
\hline & & & 2946 & 2946 & 2949 & 2946 & 2948 & $\mathrm{C}^{\beta} \mathrm{H}_{2}$ ss \\
\hline & & & 2934 & 2931 & 2936 & 2935 & 2936 & $\mathrm{C}^{\alpha} \mathrm{H}_{2}$ as \\
\hline & & & 2881 & 2880 & 2880 & 2880 & 2881 & $\mathrm{C}^{\alpha} \mathrm{H}_{2}$ ss \\
\hline & & & 2862 & 2862 & 2862 & 2862 & 2862 & $\mathrm{CH}_{3} \mathrm{sb}$ \\
\hline \multirow[t]{3}{*}{$2565 \mathrm{~s}$} & $2564 \mathrm{~s}$ & $2560 \mathrm{~s}$ & 2570 & 2570 & 2573 & 2570 & 2573 & $\mathrm{SH} \mathrm{s}$ \\
\hline & & & 1468 & 1468 & 1468 & 1468 & 1468 & $\mathrm{CH}_{3} \mathrm{ab} 2$ \\
\hline & $1458 \mathrm{~s}$ & $1458 \mathrm{~s}$ & & & & & & \\
\hline \multirow[t]{3}{*}{$1450 \mathrm{~s}$} & & & 1467 & 1467 & 1466 & 1467 & 1467 & $\mathrm{CH}_{3} \mathrm{ab} 1$ \\
\hline & $1440 \mathrm{~s}$ & $1440 \mathrm{~s}$ & 1442 & 1435 & 1449 & 1440 & 1449 & $\mathrm{C}^{\beta} \mathrm{H}_{2} \mathrm{~b}$ \\
\hline & & & 1424 & 1424 & 1425 & 1426 & 1428 & $\mathrm{C}^{\alpha} \mathrm{H}_{2} \mathrm{~b}$ \\
\hline $1380 \mathrm{~s}$ & $1380 \mathrm{~s}$ & $1380 \mathrm{~m}$ & 1376 & 1377 & 1376 & 1376 & 1376 & $\begin{array}{l}\mathrm{CH}_{3} \mathrm{sb} \\
290+1030=1320\end{array}$ \\
\hline \multirow[t]{2}{*}{$1340 w$} & $1339 \mathrm{~m}$ & $1340 \mathrm{~m}$ & & & & & & \\
\hline & & & & 1309 & & & & $\begin{array}{l}2 \times 655=1310 \\
\mathrm{C}^{\alpha} \mathrm{H}_{2} \mathbf{w}\end{array}$ \\
\hline $1298 \mathrm{~s}$ & $1298 \mathrm{~s}$ & $1297 \mathrm{~s}$ & 1294 & 1285 & 1285 & 1283 & 1287 & $\begin{array}{l}\mathrm{C}^{\alpha} \mathrm{H}_{2} \mathbf{w} \\
\mathrm{C}^{\beta} \mathrm{H}_{2} \mathbf{w}\end{array}$ \\
\hline $1240 \mathrm{~s}$ & $1246 \mathrm{~s}$ & $1249 \mathrm{~s}$ & $\begin{array}{l}1259 \\
1228\end{array}$ & & 1256 & $\begin{array}{l}1257 \\
1218\end{array}$ & 1252 & $\begin{array}{l}\mathrm{C}^{\beta} \mathrm{H}_{2} \mathrm{w} \\
\mathrm{C}^{\beta} \mathrm{H}_{2} \mathrm{tw}\end{array}$ \\
\hline \multirow[t]{2}{*}{$1225 \mathrm{sh}$} & $1225 \mathrm{~s}$ & $1221 \mathrm{~s}$ & & & 1228 & & & $\mathrm{C}^{\alpha} \mathrm{H}_{2}$ tw \\
\hline & $1208 \mathrm{sh}$ & & & 1209 & & & 1197 & $\mathrm{C}^{\beta} \mathbf{H}_{2}$ tw \\
\hline \multirow{2}{*}{$1210 \mathrm{w}$} & & & 1162 & 1204 & 1141 & 1203 & 1207 & $\begin{array}{l}\mathrm{C}^{\alpha} \mathrm{H}_{2} \text { tw } \\
\mathrm{C}^{\beta} \mathbf{H}_{2} \text { tw }\end{array}$ \\
\hline & & & & 1126 & & 1100 & & $\begin{array}{l}\mathrm{CSH} \mathrm{b} \mathrm{C}{ }^{\alpha} \mathrm{H}_{2} \mathrm{tw} \\
\mathrm{C}^{\beta} \mathbf{H}_{2} \mathbf{r}\end{array}$ \\
\hline $1105 \mathrm{~m}$ & $1105 \mathrm{~s}$ & $1108 \mathrm{~s}$ & 1085 & & & & & $\begin{array}{l}290+810=1100 \\
\mathrm{CH}_{3} \mathbf{r} 2\end{array}$ \\
\hline \multirow[t]{2}{*}{$1085 \mathrm{~s}$} & $1088 \mathrm{~s}$ & $1082 \mathrm{~m}$ & & & 1091 & & & $\mathrm{CC}^{\alpha} \mathrm{s}$ \\
\hline & & & 1062 & & 1054 & & 1044 & $\mathrm{C}^{\alpha} \mathrm{H}_{2}$ tw \\
\hline \multirow[t]{2}{*}{$1060 w$} & $1060 \mathrm{sh}$ & $1062 \mathrm{~m}$ & & 1057 & & 1059 & 1069 & $\begin{array}{l}\mathrm{CH}_{3} \mathrm{r} 2 \\
\mathrm{CC}^{\alpha} \mathrm{s}\end{array}$ \\
\hline & $961 \mathrm{vw}$ & $960 \mathrm{w}$ & $\begin{array}{r}1029 \\
961\end{array}$ & 1028 & 1026 & 1022 & 1029 & $\begin{array}{l}\mathrm{CC}^{\alpha} \mathrm{s} \\
\mathrm{CSH} \mathrm{b}\end{array}$ \\
\hline $961 \mathrm{vw}$ & $925 w$ & $918 w$ & & 928 & 937 & 945 & 940 & $\begin{array}{l}\mathrm{CSH} \text { b } \\
\mathrm{CSH} \mathrm{b}\end{array}$ \\
\hline \multirow[t]{2}{*}{$890 \mathrm{~s}$} & 892 s & $891 v s$ & 898 & & & & & $\mathrm{C}^{\alpha} \mathrm{C}^{\beta} \mathrm{s}$ \\
\hline & & & & 883 & & 884 & & $\mathrm{C}^{\alpha} \mathrm{C}^{\beta} \mathbf{s}$ \\
\hline \multirow[t]{4}{*}{$880 \mathrm{sh}$} & $880 \mathrm{~m}$ & 880 sh & & & & & & \\
\hline & & & & & 871 & & 875 & $\mathrm{C}^{\beta} \mathrm{H}_{2} \mathrm{r}$ \\
\hline & & & & & 847 & & 851 & $\mathrm{C}^{\alpha} \mathrm{C}^{\beta} \mathrm{s}$ \\
\hline & & & & & & 837 & & $\mathrm{CH}_{3} \mathrm{r} 1$ \\
\hline $815 w$ & $815 w$ & $810 \mathrm{~s}$ & 806 & 815 & 802 & & & $\mathrm{C}^{\alpha} \mathrm{H}_{2} \mathbf{r}$ \\
\hline $793 \mathrm{~s}$ & $793 \mathrm{~s}$ & $790 \mathrm{sh}$ & & 791 & & & & $\mathrm{C}^{\beta} \mathrm{H}_{2} \mathbf{r}$ \\
\hline \multirow[t]{3}{*}{$780 w$} & $779 \mathrm{sh}$ & $780 \mathrm{w}$ & 781 & & & & & $\mathrm{C}^{\beta} \mathrm{H}_{2} \mathrm{r}$ \\
\hline & & & & & & & 781 & $\mathrm{C}^{\alpha} \mathrm{H}_{2} \mathbf{r}$ \\
\hline & & & & & & 744 & & $\mathrm{C}^{\beta} \mathrm{H}_{2} \mathbf{r}$ \\
\hline
\end{tabular}


Table VIII (Continued from the previous page)

\begin{tabular}{|c|c|c|c|c|c|c|c|c|}
\hline \multicolumn{3}{|c|}{$\nu(o b s)^{a}$} & \multicolumn{5}{|c|}{$\nu($ calc $)$} & \multirow[b]{2}{*}{ Mode $^{b}$} \\
\hline$\nu(\mathrm{g})$ & $\nu\left(l_{R}\right)$ & $\nu\left(\mathrm{l}_{\mathrm{L}}\right)$ & TG & GG & $\mathrm{TT}$ & $\mathrm{G}^{\prime} \mathrm{G}$ & $\mathrm{GT}$ & \\
\hline $735 \mathrm{~m}$ & $736 \mathrm{~m}$ & $736 \mathrm{vs}$ & $(736$ & & 745 & & & $\mathrm{CS} \mathrm{s}$ \\
\hline $710 \mathrm{~s}$ & $706 \mathrm{~m}$ & $706 \mathrm{vs}$ & & & & & & $2 \times 363=726$ \\
\hline \multirow[t]{9}{*}{$655 \mathrm{~s}$} & $655 \mathrm{~s}$ & & & 659 & & 666 & 672 & $\mathrm{CS} \mathrm{s}$ \\
\hline & & & & 472 & & 478 & 467 & $\begin{array}{l}\text { CCC d } \\
290+118=408\end{array}$ \\
\hline & $417(0)$ & & & & & & & \\
\hline & & & & & & & & $290+135=425$ \\
\hline & $363(5)$ & & 365 & & 364 & & & $\mathrm{CCC} \mathrm{d}$ \\
\hline & $290(0.5)$ & & 274 & 274 & 252 & 297 & 278 & $\operatorname{CCS} d$ \\
\hline & $230(0)$ & & 236 & 230 & 218 & 221 & 205 & $\mathrm{CS} \mathrm{t}$ \\
\hline & & & 141 & 135 & 142 & 137 & 135 & $\mathrm{CC}^{\alpha} \mathrm{t}$ \\
\hline & & & 118 & 110 & 114 & 111 & 106 & $\mathrm{C}^{\alpha} \mathrm{C}^{\beta} \mathrm{t}$ \\
\hline
\end{tabular}

${ }^{*}$ From Ref. 12 , for gas, room-temperature liquid, and low-temperature $\left(-120^{\circ} \mathrm{C}\right)$ liquid. Raman intensities of $417-230-\mathrm{cm}^{-1}$ bands from Ref. 17.

${ }^{b}$ Only major contributor is given, except for 1126 (GG), where both components are essentially equal. s: Stretch; ss: symmetric stretch; as: antisymmetric stretch; b: bend; sb: symmetric bend; ab: antisymmetric bend; d: deformation; w: wag; tw: twist, r: rock; t: torsion.

tion for frequencies $<1700 \mathrm{~cm}^{-1}$, which is highest for these conformers. Another criterion might be the number of modes that show very large deviation, say $\geq 20 \mathrm{~cm}^{-1}$. Such a "sieve" leaves three favorable cases: $\mathrm{SGG}, \mathrm{G}^{\prime} \mathrm{G}^{\prime} \mathrm{G}$, and $\mathrm{SG}^{\prime} \mathrm{G}$. The last is disfavored by a large discrepancy for the amide $\mathrm{V}$ mode and the first by a large discrepancy for the $\mathrm{CSH} b$ mode. Thus, the $G^{\prime} G^{\prime} G$ conformer, which is overall the most favored on these (as well as other) criteria, seems to be the most likely structure in solution. Its structure is shown in Figure 2, and we present a complete description of its normal modes in Table $\mathrm{X}$, with scale factors being given in Table IV. While this procedure may not guarantee a unique structural solution, it should provide a test of whether the ET force field (or a very slight modification of it) can be transferred to a system in which there are peptide groups adjacent to the $-\mathrm{CH}_{2} \mathrm{SH}$ group, as in proteins.

As can be seen from Table X, the agreement between observed and calculated frequencies is quite good: the average discrepancy for bands below 1700 $\mathrm{cm}^{-1}$ is $4.3 \mathrm{~cm}^{-1}$, compared to 5.7 for $1 \mathrm{PT}$ and 3.0 for ET. The assignments are reasonable and (not surprisingly) differ in some cases from those previously proposed on empirical grounds. ${ }^{32}$ We have also calculated the normal modes of the ND,SD molecule, and these compare well with the experimental data. ${ }^{32}$ The $\nu(\mathrm{SH})$ frequency does not depend on $\chi^{1}$ and has a small sensitivity to $\chi^{2}$. Since $\partial \nu(\mathrm{SH}) / \partial f(\mathrm{H} \cdots \mathrm{O})$ is positive, the lower $\nu(\mathrm{SH})$ (compared to ET), with the required smaller $f(\mathrm{SH})$, reflects the hydrogen bonding of this group. The shift on deuteration to $1875 \mathrm{~cm}^{-1}$ ( calculated at 1865 $\mathrm{cm}^{-1}$ ) is reasonably well predicted considering the anharmonicity difference. Amide I at 1634 shifts to $1631(1621) \mathrm{cm}^{-1}$ and amide II at 1583 shifts to 1496 (1492) $\mathrm{cm}^{-1}$ on deuteration. The $1373-\mathrm{cm}^{-1}$ band shifts to $1335\left(1321, \mathrm{C}^{\alpha} \mathrm{H}_{2}\right.$ wag (w) ) $\mathrm{cm}^{-1}$ on deuteration, a shift that is reasonably well predicted for this partially amide III mode. (It may be possible that a Fermi resonance with $2 \times 673=1346$ also contributes to the observed $1373-$ and $1316-\mathrm{cm}^{-1}$ pair.) The three $\mathrm{CH}_{2} \mathrm{w}$ and $\mathrm{CH}_{2}$ twist (tw) modes at 1292,1280 , and $1209 \mathrm{~cm}^{-1}$ are replaced by two

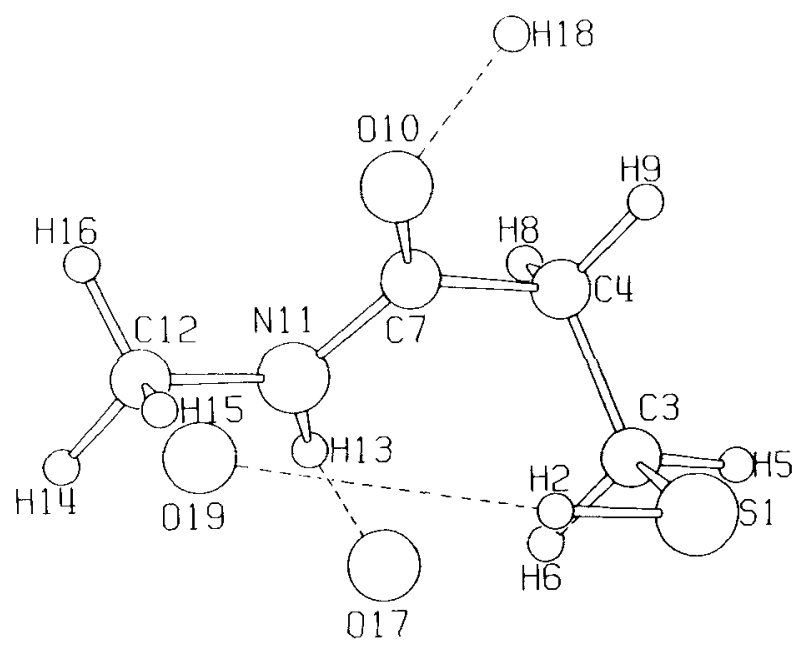

Figure 2. Structure of $\mathrm{G}^{\prime} \mathrm{G}^{\prime} \mathrm{G}$ conformer of 3TNMP. 
Table IX Measures of Agreement Between Calculated ${ }^{a}$ and Observed ${ }^{b}$ Frequencies of Conformers of 3TNMP

\begin{tabular}{|c|c|c|c|c|c|}
\hline Conformer ${ }^{c}$ & $|\Delta \nu(\mathrm{CS})|^{\mathrm{d}}$ & $\langle|\Delta \nu|\rangle^{c}$ & $\mathrm{~N}(|\Delta \nu| \geq 20)^{\mathrm{f}}$ & $|\Delta \nu(\mathrm{V})|^{\mathrm{g}}$ & $|\Delta \nu(\mathrm{CSH})|^{\mathrm{h}}$ \\
\hline $\mathrm{S}^{\prime} \mathrm{TG}$ & 14 & 14.4 & 3 & 6 & 20 \\
\hline G"TG & 28 & 13.2 & 5 & 11 & 9 \\
\hline GTG & 20 & 13.1 & 5 & 9 & 16 \\
\hline STG & 19 & 11.6 & 3 & 9 & 8 \\
\hline TTG & $14,126^{\mathrm{i}}$ & 10.6 & 3 & 13 & 7 \\
\hline$S^{\prime} G G$ & 7 & 8.6 & 2 & 11 & 6 \\
\hline $\mathrm{G}^{\prime} \mathrm{GG}$ & 3 & 10.1 & 4 & 9 & 2 \\
\hline GGG & 8 & 9.7 & 3 & 5 & 6 \\
\hline SGG & 1 & 6.0 & 0 & 8 & 14 \\
\hline TGG & 84 & 7.9 & 2 & 9 & 3 \\
\hline$S^{\prime} G^{\prime} G$ & 1 & 8.4 & 3 & 6 & 1 \\
\hline $\mathrm{G}^{\prime} \mathrm{G}^{\prime} \mathrm{G}$ & 2 & 4.3 & 0 & 7 & 0 \\
\hline $\mathrm{GG}^{\prime} \mathrm{G}$ & 4 & 8.6 & 3 & 8 & 0 \\
\hline $\mathrm{SG}^{\prime} \mathrm{G}$ & 6 & 8.3 & 0 & 47 & 10 \\
\hline TG'G & 91 & 7.7 & 3 & 2 & 2 \\
\hline
\end{tabular}

${ }^{a}$ Based on least-squares refinement of force field for each conformer (see text).

${ }^{b}$ From Ref. 32.

${ }^{c} \psi \chi^{1} \chi^{2}$ dihedral angles. Prime indicates negative angle.

d Magnitude of difference between observed and calculated CS stretch mode, in $\mathrm{cm}^{-1}$.

${ }^{e}$ Average magnitude of difference between observed and calculated frequencies, in $\mathrm{cm}^{-1}$.

f Number of discrepancies whose magnitude is $\geq 20 \mathrm{~cm}^{-1}$.

${ }^{\mathrm{g}}$ Magnitude of difference between observed and calculated amide $V$ frequencies, in $\mathrm{cm}^{-1}$.

${ }^{h}$ Magnitude of difference between observed and calculated CSH bend mode, in $\mathrm{cm}^{-1}$.

i $\mathrm{CS}$ stretch divided between two modes.

bands on deuteration, $1287\left(1275, \mathrm{C}^{\alpha} \mathrm{H}_{2}\right.$ tw, $\mathrm{C}^{\beta} \mathrm{H}_{2}$ w) and $\sim 1232\left(1219, \mathrm{C}^{\beta} \mathrm{H}_{2} \mathrm{w}\right) \mathrm{cm}^{-1}$, while bands at 1168,1084 , and $1025 \mathrm{~cm}^{-1}$ shift only slightly [although the 1091- (1107) $-\mathrm{cm}^{-1}$ band is now completely $\mathrm{CH}_{3} \mathrm{r} 2$ ]. The ND in-plane bend (ib) mode appears as a new medium band at $990(981) \mathrm{cm}^{-1}$, while the $881-, 807-$, and $770-\mathrm{cm}^{-1}$ bands reorganize into modes at $895\left(902, \mathrm{C}^{\alpha} \mathrm{H}_{2} \mathrm{r}\right), 848\left(830, \mathrm{CH}_{3} \mathrm{r} 1\right.$, $\mathrm{CN} \mathrm{s}, \mathrm{C}^{\beta} \mathrm{H}_{2} \mathrm{r}, \mathrm{CC}^{\alpha} \mathrm{s}$ ), and 767 (777, CO out-ofplane bend $(\mathrm{ob})) \mathrm{cm}^{-1}$. The $\nu$ (CS) mode shifts from 673 to $680(679) \mathrm{cm}^{-1}$, and CCS d shifts from 369 to $355(360) \mathrm{cm}^{-1}$. This general level of agreement for the deuterated molecule supports the validity of the force field and the assignments for 3TNMP, and provides the basis for a confident transfer of the ET force field to a model of the cysteine residue in proteins.

\section{PROTEIN MODEL FOR CYSTEINE RESIDUE}

The model system chosen to calculate the conformation dependence of $\nu(\mathrm{SH})$ and $\nu(\mathrm{CS})$ of the cysteine residue in proteins, following our experience with similar calculations on the disulfide bridge, ${ }^{24}$ was

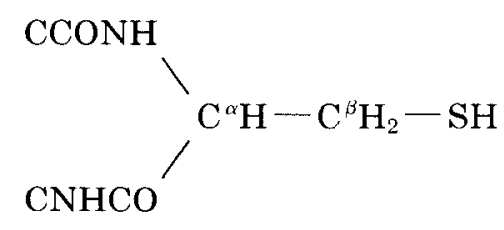

which is shown in Figure 3. The force field consisted of our ab initio force field for ET combined with our empirical force field for the peptide group,,$^{34}$ a procedure that proved to be satisfactory in the analysis of the disulfide bridge. ${ }^{24}$ The $\mathrm{SH}$ group was left nonhydrogen bonded, since this only affects $f(\mathrm{SH})$ and we are interested here in the conformation dependence of $\nu(\mathrm{SH})$. The structure is determined by $\chi^{2}$, $\chi^{1}$ [taken as $\left.\tau\left(\mathrm{NC}^{\alpha} \mathrm{C}^{\beta} \mathrm{S}\right)\right]$, and $(\phi, \psi)$. The calculations were done for $\chi^{2}=180^{\circ}(\mathrm{T}),-150^{\circ}\left(\mathrm{D}^{\prime}\right)$, $-120^{\circ}\left(\mathrm{S}^{\prime}\right),-90^{\circ}\left(\mathrm{B}^{\prime}\right),-60^{\circ}\left(\mathrm{G}^{\prime}\right),-30^{\circ}\left(\mathrm{A}^{\prime}\right), 0^{\circ}$ (C), $30^{\circ}(\mathrm{A}), 60^{\circ}(\mathrm{G}), 90^{\circ}(\mathrm{B}), 120^{\circ}(\mathrm{S})$, and $150^{\circ}$ (D); $\chi^{1}=180^{\circ}(\mathrm{N}),-60^{\circ}(\mathrm{C})$, and $60^{\circ}(\mathrm{H})$; and $(\phi, \psi)=\alpha\left(-57.4^{\circ},-47.5^{\circ}\right), \gamma\left(-86.9^{\circ},-3.0^{\circ}\right), \beta$ $\left(-138.4^{\circ}, 135.7^{\circ}\right)$, and $\epsilon\left(-80^{\circ}, 142^{\circ}\right)$ (the $\gamma$ structure corresponds to that in glutathione, ${ }^{27}$ and the $\epsilon$ structure is the average extended-helix conformation ${ }^{26}$ ). The $\chi^{2}$ dependence of the force 
Table X Observed and Calculated Frequencies (in $\mathrm{cm}^{-1}$ ) of G'G'G 3TNMP

\begin{tabular}{|c|c|c|c|c|}
\hline \multicolumn{3}{|c|}{$\nu(\mathrm{obs})^{\mathrm{a}}$} & \multirow[b]{3}{*}{$\nu($ calc $)$} & \multirow[b]{3}{*}{$\mathrm{PED}^{\mathrm{b}}$} \\
\hline \multicolumn{2}{|c|}{ Solid } & \multirow[b]{2}{*}{ Solution $\mathrm{R}$} & & \\
\hline IR & $\mathrm{R}$ & & & \\
\hline $2572 \mathrm{vs}$ & $2573 v s$ & $2582 \mathrm{vs}$ & 2596 & SH s(96) \\
\hline $1640 \mathrm{~s}$ & $1639 \mathrm{~s}$ & $1634 \mathrm{~m}$ & 1636 & $\mathrm{CO}$ s $(66) \mathrm{NH}$ ib(21) \\
\hline \multirow[t]{5}{*}{$1560 \mathrm{~s}$} & $1559_{\mathrm{w}}$ & $1583 w$ & 1586 & $\mathrm{NH}$ ib(45) CN s(42) CO s(15) \\
\hline & $1469 \mathrm{w}$ & $1461 \mathrm{sh}$ & 1463 & $\mathrm{CH}_{3}$ ab2(67) $\mathrm{CH}_{3}$ ab1(22) \\
\hline & & & 1451 & $\mathrm{C}^{\alpha} \mathrm{H}_{2} \mathrm{~b}(93)$ \\
\hline & $1432 w$ & $1432 \mathrm{~m}$ & 1433 & $\mathrm{CH}_{3}$ ab1(73) $\mathrm{CH}_{3}$ ab2(24) \\
\hline & $1426 \mathrm{~s}$ & $1420 \mathrm{~m}$ & 1419 & $\mathrm{C}^{\beta} \mathrm{H}_{2} \mathrm{~b}(85)$ \\
\hline $1407 \mathrm{~m}$ & & & 1407 & $\mathrm{CH}_{3} \mathrm{sb}(86)$ \\
\hline \multirow[t]{3}{*}{$1370 \mathrm{w}$} & $1372 w$ & $1373 \mathrm{~m}$ & 1355 & $\begin{array}{l}\mathrm{C}^{\alpha} \mathrm{H}_{2} \mathrm{w}(33) \mathrm{CC}^{\alpha} \mathrm{s}(20) \mathrm{CN} \text { s(14) } \\
\mathrm{NH} \text { ib(13) } \mathrm{CH}_{3} \mathrm{sb}(11)\end{array}$ \\
\hline & & $1316 \mathrm{sh}$ & & $598+720=1318$ \\
\hline & & $1292 \mathrm{~m}$ & 1292 & $\mathrm{C}^{\alpha} \mathrm{H}_{2} \mathrm{w}(53) \mathrm{CN} \mathrm{s}(11)$ \\
\hline $1275 \mathrm{~s}$ & $1272 \mathrm{~m}$ & $1280 \mathrm{~m}$ & 1277 & $\mathrm{C}^{\alpha} \mathrm{H}_{2} \mathrm{tw}(27) \mathrm{C}^{\beta} \mathrm{H}_{2} \mathrm{w}(27) \mathrm{C}^{\beta} \mathrm{H}_{2} \operatorname{tw}(15)$ \\
\hline $1217 \mathrm{~s}$ & $1222 w$ & $1209 w$ & 1217 & $\mathrm{C}^{\beta} \mathrm{H}_{2} \mathrm{w}(74) \mathrm{C}^{\alpha} \mathrm{H}_{2} \mathrm{tw}(19)$ \\
\hline \multirow[t]{3}{*}{$1162 \mathrm{~s}$} & $1162 \mathrm{~m}$ & $1168 \mathrm{~m}$ & 1167 & $\mathrm{C}^{\beta} \mathrm{H}_{2}$ tw $(54) \mathrm{C}^{\alpha} \mathrm{H}_{2}$ tw(24) $\mathrm{CSH} b(11)$ \\
\hline & & & 1149 & $\mathrm{CH}_{3} \mathrm{r} 1(55) \mathrm{NC} s(14)$ \\
\hline & & & 1108 & $\mathrm{CH}_{3} \mathbf{r} 2(85)$ \\
\hline $1090 \mathrm{sh}$ & $1090 \mathrm{w}$ & $1084 w$ & 1084 & $\mathrm{NC} \mathrm{s}(50) \mathrm{CC}^{\alpha} \mathrm{s}(16)$ \\
\hline $1033 \mathrm{sh}$ & $1032 w$ & $1025 w$ & 1025 & $\mathrm{C}^{\alpha} \mathbf{C}^{\beta} \mathbf{s}(71)$ \\
\hline \multirow[t]{2}{*}{$977 \mathrm{w}$} & $982 w$ & $981 w$ & 981 & $\mathrm{CSH} b(40) \mathrm{C}^{\beta} \mathrm{H}_{2} \mathrm{tw}(23) \mathrm{C}^{\beta} \mathrm{H}_{2} \mathbf{r}(10)$ \\
\hline & & $945 \mathrm{w}$ & & $275+673=948$ \\
\hline 910 s & $911 \mathrm{vs}$ & $912 \mathrm{~m}$ & 908 & $\mathrm{C}^{\alpha} \mathrm{H}_{2} \mathrm{r}(63)$ \\
\hline \multirow[t]{3}{*}{$860 \mathrm{~m}$} & $860 \mathrm{~m}$ & $881 \mathrm{~m}$ & 874 & $\mathrm{CN} \mathrm{s(17)} \mathrm{CSH} \mathrm{b(14)} \mathrm{CH}_{3} \mathrm{r} 1(13)$ \\
\hline & & & & $\mathrm{CC}^{\alpha} \mathrm{s}(11)$ \\
\hline & 800 sh & $807 w$ & 804 & $\mathrm{CO}$ ob(17) $\mathrm{C}^{\beta} \mathrm{H}_{2} \mathrm{r}(17) \mathrm{CO} \mathrm{ib}(12)$ \\
\hline $765 \mathrm{sh}$ & $767 \mathrm{~m}$ & $770 \mathrm{w}$ & 766 & $\mathrm{C}^{\beta} \mathrm{H}_{2} \mathbf{r}(36) \mathrm{CO}$ ob(35) $\mathrm{CSH} b(10)$ \\
\hline $720 \mathrm{vs}$ & & & 713 & $\mathrm{CN}$ t(37) $\mathrm{NH}$ ob(17) $\mathrm{NH} t(12)$ \\
\hline $673 \mathrm{~s}$ & $671 \mathrm{~m}$ & $673 \mathrm{vs}$ & 675 & $\operatorname{CS~s}(71)$ \\
\hline $583 \mathrm{~s}$ & $584 w$ & $598 \mathrm{~m}$ & 592 & $\mathrm{CC}^{\alpha \mathrm{s}} \mathrm{s}(23) \mathrm{CO} \mathrm{ib}(22)$ \\
\hline $435 \mathrm{~s}$ & $437 \mathrm{~s}$ & $442 \mathrm{~m}$ & 455 & $\mathrm{C}^{\alpha} \mathrm{CN} d(32) \mathrm{CO} \mathrm{ib}(29) \operatorname{CCC} \mathrm{d}(10)$ \\
\hline $363 w$ & & $369 w$ & 364 & $\operatorname{CCS} d(58) \operatorname{CCC} d(15)$ \\
\hline \multirow[t]{10}{*}{$278 w$} & $278 v s$ & $275 \mathrm{~m}$ & 288 & CNC d(40) CS t(18) CCC d(12) \\
\hline & & & & $\mathrm{CO} \mathrm{ib}(11)$ \\
\hline & & & 251 & $\mathrm{CS} \mathrm{t}(57) \mathrm{CNC} d(20) \mathrm{C}^{\alpha} \mathrm{CN} \mathrm{d}(13)$ \\
\hline & & & 191 & $\begin{array}{l}\mathrm{CCC} \mathrm{d}(24) \mathrm{C}^{\alpha} \mathrm{CN} d(20) \mathrm{SH} \cdots \mathrm{O} \\
\quad \mathbf{s}(19)\end{array}$ \\
\hline & & & 149 & $\mathrm{NC} t(92)$ \\
\hline & & & 126 & $\mathrm{NH} \mathrm{ob}(61) \mathrm{CN} t(45)$ \\
\hline & & & 63 & $\mathrm{C}^{\alpha} \mathrm{C}^{\beta} \mathrm{t}(33) \mathrm{NH} \cdots \mathrm{O}$ b(17) $\mathrm{NH} t(15)$ \\
\hline & & & 42 & NH $t(62) \mathrm{CN} t(13)$ \\
\hline & & & 24 & $\operatorname{CO} t(94)$ \\
\hline & & & 8 & $\mathrm{SH} t(79) \mathrm{CS} t(11)$ \\
\hline
\end{tabular}

${ }^{\mathrm{a}}$ From Ref. 32.

b Contributions to potential energy distribution $\geq 10$. s: Stretch; ss: symmetric stretch; as: antisymmetric stretch; b: bend; sb: symmetric bend; ab: antisymmetric bend; ib: in-plane bend; ob: out-of-plane bend; $d$ : deformation; w: wag; tw: twist, r: rock; t: torsion.

field was incorporated in the calculation, as in the case of the disulfide bridge. ${ }^{24}$

The calculated $\nu(\mathrm{SH})$ and $\nu(\mathrm{CS})$ frequencies of these 144 structures are given in Table XI. The calculated $\chi^{2}$ dependence of $\nu(\mathrm{SH})$ of ET is reproduced here, i.e., $\Delta \nu(\mathrm{T}-\mathrm{G})=3 \mathrm{~cm}^{-1}$, but we see that the 


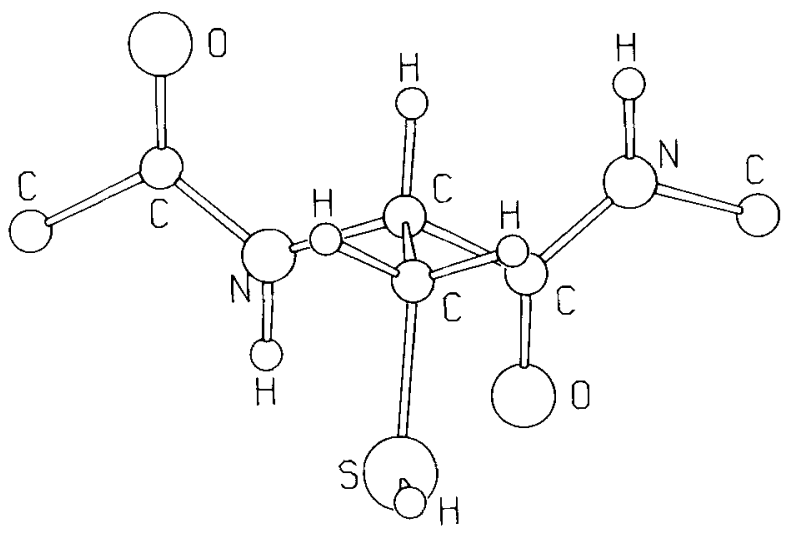

Figure 3. Structure of model for calculations of normal modes of cysteine residue in proteins. maximum variation can be $14 \mathrm{~cm}^{-1}$, viz., $\Delta \nu(\mathrm{S}-\mathrm{G})$. Since the observed ET difference is much larger, viz., $9 \mathrm{~cm}^{-1}$, we expect that the observed conformational variation of $\nu(\mathrm{SH})$ in proteins will be significantly larger than the predicted $14 \mathrm{~cm}^{-1}$. Of course, this will be influenced by the effects of hydrogen bonding, so caution will be needed in inferring $\chi^{2}$ from $\nu(\mathrm{SH})$.

With respect to $\nu(\mathrm{CS})$, we see that, as in the case of the disulfide bridge, ${ }^{26}$ it depends strongly on $\chi^{2}$ and $\chi^{1}$, and particularly on $\phi, \psi$. The dependence is not exactly the same for the two structures, and the overlapping regions are different. In Table XII we present the $\chi^{2}$ frequency ranges for the dominant $\nu$ (CS) mode as a function of $\chi^{1} \phi, \psi$, and it can be

Table XI Cysteine Residue SH and CS Stretch Frequencies (in $\mathrm{cm}^{-1}$ )

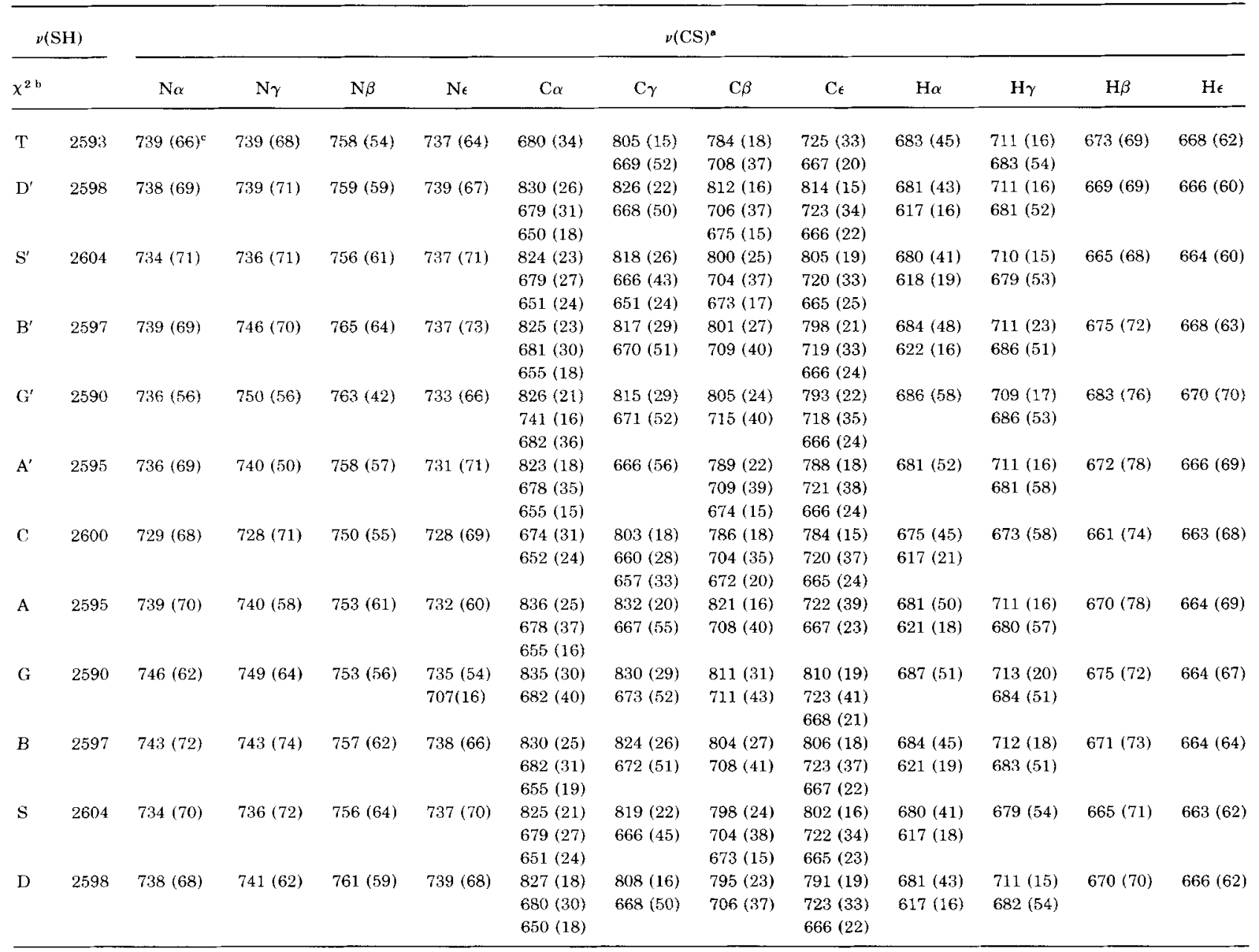

${ }^{\mathrm{a}} \chi^{1}=\tau\left(\mathrm{NC}^{\alpha} \mathrm{C}^{\beta} \mathrm{S}\right), \mathrm{N}, \mathrm{C}, \mathrm{H}$ are atoms trans to $\mathrm{S} . \alpha, \gamma, \beta, \epsilon=\varphi, \psi: \alpha=-57.4^{\circ},-47.5^{\circ} ; \gamma=-86.9^{\circ},-3.0^{\circ} ; \beta=-138.4^{\circ}, 135.7^{\circ}, \epsilon$ $=-80^{\circ}, 142^{\circ}$.

${ }^{\mathrm{b}} \chi^{2}=\tau\left(\mathrm{C}^{\alpha} \mathrm{C}^{\beta} \mathrm{SH}\right) . \mathrm{T}=180^{\circ}, \mathrm{D}=150^{\circ}, \mathrm{S}=120^{\circ}, \mathrm{B}=90^{\circ}, \mathrm{G}=60^{\circ}, \mathrm{A}=30^{\circ}$; prime indicates negative angle.

c Potential energy distribution in $\mathrm{CS}$ stretch $\geq 15$. 
Table XII Frequency Ranges of CS Stretch Frequencies $^{\mathrm{a}}\left(\right.$ in $\mathrm{cm}^{-1}$ ) of Cysteine Residues in Proteins

\begin{tabular}{cc}
\hline$\chi^{1} \varphi, \psi^{\mathrm{b}}$ & Range \\
\hline $\mathrm{N} \alpha$ & $729-746$ \\
$\mathrm{~N} \gamma$ & $728-750$ \\
$\mathrm{~N} \beta$ & $750-765$ \\
$\mathrm{~N} \epsilon$ & $728-739$ \\
$\mathrm{C} \alpha$ & $674-682$ \\
$\mathrm{C} \gamma$ & $657-673$ \\
$\mathrm{C} \beta$ & $704-715$ \\
$\mathrm{C} \epsilon$ & $718-725$ \\
$\mathrm{H} \alpha$ & $680-687$ \\
$\mathrm{H} \gamma$ & $679-686$ \\
$\mathrm{H} \beta$ & $661-683$ \\
$\mathrm{H} \epsilon$ & $663-670$ \\
\hline
\end{tabular}

${ }^{a}$ For the dominant $\mathrm{CS}$ stretch mode from Table XI.

${ }^{\mathrm{b}} \chi^{1}=\tau\left(\mathrm{NC}^{\alpha} \mathrm{C}^{\beta} \mathrm{S}\right), \mathrm{N}, \mathrm{C}, \mathrm{H}$ are atoms trans to $\mathrm{S} . \alpha, \gamma, \beta, \epsilon=\varphi$, $\psi: \alpha=-57.4^{\circ},-47.5^{\circ} ; \gamma=-86.9^{\circ},-3.0^{\circ} ; \beta=-138.4^{\circ}, 135.7^{\circ}, \epsilon$ $=-80^{\circ}, 142^{\circ}$.

seen that though there is overlap in other regions, these are unique for $\mathrm{N} \beta, \mathrm{C} \beta$, and $\mathrm{C} \epsilon$. Within each of these regions, $\chi^{2}$ can be (though less uniquely) characterized from the dependence given in Table XI. Of course, as in the disulfide case, ${ }^{26}$ not all $\chi^{2} \chi^{1} \phi, \psi$ may be found with equal probability in proteins. When sufficient structural data are available to compile such statistics, then, as with the disulfide bridge, ${ }^{26}$ it will be possible to narrow the conformational probabilities on the basis of such information.

At present, detailed experimental data to compare to the predictions in Table XI are highly limited. The structure of glutathione is known, ${ }^{37}$ and the cysteine residue in it has a conformation close to $\mathrm{BH} \gamma$. Our predicted $\nu(\mathrm{CS})$ is $682 \mathrm{~cm}^{-1}$, and the spectra show a strong Raman band at $679 \mathrm{~cm}^{-1}$ and a shoulder in the ir at $682 \mathrm{~cm}^{-1},{ }^{27}$ in excellent agreement with our calculation. A neutron diffraction structure of orthorhombic L-cysteine is known, ${ }^{38}$ and although it is not exactly relevant since it does not contain peptide groups, it probably can serve to verify the general range for $\nu$ (CS). The unit cell has molecules whose conformation is close to $\mathrm{GH}$ and $\mathrm{G}^{\prime} \mathrm{H}$, and the observed $\nu(\mathrm{CS})$ mode is at $\sim 690$ $\mathrm{cm}^{-1} \cdot{ }^{18,28}$ Our predicted value, averaging over $\phi, \psi$, is $\sim 680 \mathrm{~cm}^{-1}$, which is probably reasonable given the different structures. In monoclinic L-cysteine, ${ }^{39}$ the unit cell has molecules whose conformations are close to $\chi^{1}=\mathrm{H}$ and $\chi^{1}=\mathrm{N}$ [ the $\mathrm{x}$-ray structure determination did not identify the $(\mathrm{S}) \mathrm{H}]$, and $\nu$ (CS) Raman bands are observed at 677 and 737 $\mathrm{cm}^{-1} .{ }^{18}$ The former frequency is clearly consistent with a $\chi^{1}=\mathrm{H}$ conformation and the latter with a $\chi^{1}=\mathrm{N}$ conformation (but not with $\chi^{1}=\mathrm{C}$, as possibly suggested ${ }^{18}$ ). These examples thus provide support for the validity of the calculated frequencies given in Table XI as being reliable indicators of cysteine residue geometry.

\section{CONCLUSIONS}

The development of a reliable ab initio force field for the $-\mathrm{CH}_{2} \mathrm{SH}$ group has enabled us to make definitive predictions about the conformational dependence of $\nu(\mathrm{SH})$ and $\nu(\mathrm{CS})$ of the cysteine residue in proteins. In the case of the strong Raman $\nu(\mathrm{SH})$ mode, the frequency shift due to hydrogen bonding is superimposed on a conformational variation, so separating these two effects must be taken into account. For the weaker Raman $\nu$ (CS) mode, it is of course necessary that a correct identification of this band be made in the spectrum. If this is done, the calculated frequencies given here can provide a more specific assignment of conformation than was previously possible on the basis of simple model compound correlations.

This research was supported by NSF grants DMB- 8816756 and DMR-9110353.

\section{REFERENCES}

1. Bare, G. H., Alben, J. O. \& Bromberg, P. A. (1975) Biochemistry 14, 1578-1583.

2. Moh, P. P., Fiamingo, F. G. \& Alben, J. O. (1987) Biochemistry 26, 6243-6249.

3. Yu, N.-T. \& East, E. J. (1975) J. Biol. Chem. 250 , 2196-2202.

4. Chen, W., Nie, S., Kuck, J. F. R., Jr. \& Yu, N.-T. (1991) Biophys. J. 60, 447-455.

5. Pande, J., McDermott, M. J., Callender, R. H. \& Spector, A. (1989) Arch. Biochem. Biophys. 269, 250 255.

6. Byler, D. M., Susi, H. \& Farrell, H. M., Jr. (1983) Biopolymers 22, 2507-2511.

7. Thomas, G. J., Jr., Li, Y., Fuller, M. T. \& King, J. (1982) Biochemistry 21, 3866-3878.

8. Li, T., Chen, Z., Johnson, J. E. \& Thomas, G. J., Jr. (1990) Biochemistry 29, 5018-5026.

9. Smith, D., Devlin, J. P. \& Scott, D. W. (1968) J. Mol. Spectrosc. 25, 174-184. 
10. Richter, W. \& Schiel, D. (1984) Chem. Phys. Lett. 108, 480-483.

11. Li, H. \& Thomas, G. J., Jr. (1991) J. Am. Chem. Soc $113,456-462$.

12. Hayashi, M., Shiro, Y. \& Murata, H. (1966) Bull. Chem. Soc. Jpn. 39, 112-117.

13. Scott, D. W. \& El-Sabban, M. Z. (1969) J. Mol. Spectrosc. 30, 317-337.

14. Inagaki, F., Harada, I. \& Shimanouchi, T. (1973) $J$. Mol. Spectrosc. 46, 381-396.

15. Manocha, A. S., Fateley, W. G. \& Shimanouchi, T. (1973) J. Phys. Chem. 77, 1977-1981.

16. Durig, J. R., Bucy, W. E., Wurrey, C. J. \& Carreira, L. A. (1975) J. Phys. Chem. 79, 988-993.

17. Pennington, R. E., Scott, D. W., Finke, H. L., McCullough, J. P., Messerley, J. F., Hossenlopp, I. A. \& Waddington, G. (1956) J. Am. Chem. Soc. 78, 32663272.

18. Ozaki, Y., Sugeta, H. \& Miyazawa, T. (1975) Chem Lett. 713-716.

19. Sugeta, H., Go, A. \& Miyazawa, T. (1972) Chem. Lett. 83-86.

20. Sugeta, H., Go, A. \& Miyazawa, T. (1973) Bull. Chem. Soc. Jpn. 46, 3407-3411.

21. Nogami, N., Sugeta, H. \& Miyazawa, T. (1975) Chem. Lett. 147-150.

22. Sugeta, H. (1975) Spectrochim. Acta 31A, 1729-1737.

23. Nogami, N., Sugeta, H. \& Miyazawa, T. (1975) Bull. Chem. Soc. Jpn. 48, 2417-2420.

24. Qian, W., Zhao, W. \& Krimm, S. (1991) J. Mol. Struct. 250, 89-102.
25. Qian, W. \& Krimm, S. (1992) Biopolymers, 32, 321326.

26. Qian, W. \& Krimm, S. (1992) Biopolymers, 32, 10251033.

27. Qian, W. \& Krimm, S., to be published.

28. Susi, H., Byler, D. M. \& Gerasimowicz, V. (1983) J. Mol. Struct. 102, 63-79.

29. Zhao, W., Bandekar, J. \& Krimm, S. (1988) J. Am. Chem. Soc. 110, 6891-6892.

30. Zhao, W. \& Krimm, S. (1990) J. Mol. Struct. 224, 7-20.

31. Zhao, W., Bandekar, J. \& Krimm, S. (1990) J. Mol. Struct. 238, 43-54.

32. Zuppiroli, G., Perchard, C., Baron, M. H. \& de Loze, C. (1980) J. Mol. Struct. 69, 1-16.

33. Mirkin, N. G. \& Krimm, S. (1991) J. Am. Chem. Soc. 113, 9742-9747.

34. Krimm, S. \& Bandekar, J. (1986) Adv. Protein Chem. 38, 181-364.

35. Fogarasi, G. \& Pulay, P. (1985) Vibrational Spectra and Structure, Vol. 14, Durig, J. R., Ed., Elsevier Amsterdam, Oxford, New York, Tokyo pp. 125-219.

36. Snyder, R. G. \& Schachtschneider, J. H. (1965) Spectrochim. Acta 21, 169-195.

37. Görbitz, C. H. (1987) Acta Chem. Scand. B41, 362366.

38. Kerr, K. A., Ashmore, J. P. \& Koetzle, T. F. (1975) Acta Cryst. B 31, 2022-2026.

39. Harding, M. M. \& Long, H. A. (1968) Acta Cryst. B 24, 1096-1102.

Received February 25, 1992

Accepted April 30, 1992 